\title{
THE VALUE OF FINANCIAL STATEMENT VERIFICATION IN DEBT FINANCING: EVIDENCE FROM PRIVATE U.S. FIRMS
}

\author{
by
}

\author{
Michael Craig Minnis \\ A dissertation submitted in partial fulfillment \\ of the requirements for the degree of \\ Doctor of Philosophy \\ (Business Administration) \\ in The University of Michigan \\ 2010
}

Doctoral Committee:

Professor Russell J. Lundholm, Chair

Associate Professor Amy K. Dittmar

Associate Professor Gregory S. Miller

Associate Professor Venkatesh K. Nagar

Assistant Professor Yusuf Can Masatlioglu 
(C) Michael Craig Minnis 2010 


\section{DEDICATION}

I dedicate this dissertation to my wife, Laura, to our children, Avery, Addison, and Aidan, and to my parents, William Minnis and Marian Cash - all of whom encouraged and supported me throughout the Ph.D. process. 


\section{ACKNOWLEDGEMENTS}

This dissertation is the culmination of my interactions with many people who have impacted my thinking over the years - indeed too many to list. However, a number of individuals have significantly influenced this document. First, I would like to thank my Chair, Russell Lundholm, for all of his suggestions, advice and encouragement throughout the dissertation process. Additionally, the guidance of the members of my committee Gregory Miller, Venky Nagar, Amy Dittmar, and Yusufcan Masatlioglu - has been simply invaluable.

I would also like to thank Raffi Indjejkian, Feng Li, Michal Matejka, Madhav Rajan, and Cathy Shakespeare for their support and many discussions throughout the writing of this dissertation. I have also benefited greatly from Nemit Shroff, Gwen Yu, and the other Ph.D. students at the University of Michigan who have helped me get through the Ph.D. process.

I am very grateful to my wife, Laura, who managed not only to support me, but also to raise our three children, Avery, Addison, and Aidan. I must also acknowledge the tremendous support that I received from my parents, William Minnis and Marian Cash, and my parents-in-law, Larry Kirby and Marianne Whitacre. Without them, this would not have been possible. 
I gratefully acknowledge the many insights that I received from Mike Farmer, Gene Fitzgerald, Adam Gileski, William Minnis, and the Indiana CPA Society. I also sincerely appreciate that Sageworks, Inc. was willing to provide me with their data and their time.

Finally, I gratefully acknowledge the financial support of the William A. Paton Scholarship fund and the University of Michigan Ross School of Business. 


\section{TABLE OF CONTENTS}

DEDICATION $\quad$ ii

ACKNOWLEDGEMENTS $\quad$ iii

LIST OF TABLES vii

LIST OF APPENDICES viii

$\begin{array}{ll}\text { ABSTRACT ix } & \text { ix }\end{array}$

CHAPTER

1. Introduction 1

2. Prior Literature and Hypotheses $\quad 8$

2.1 Auditing and the Interest Rate on Debt 8

2.2 Increasing Informativeness: The Information Hardening Role of an Audit 11

2.3 The Predictive Ability of Financial Statements 13

3. Private Firm Setting and Data 15

3.1 Private Firm Setting 15

3.2 Data Source and Selection 16

3.3 Variable Definitions and Descriptive Statistics 19

3.4 Correlations 25

4. Empirical Approach and Results 26 
4.1 Self Selection Bias and Estimation Issues

4.2 Modeling the Audit Choice

4.2.1 Variables Predicting Audit Choice

4.2.2 Audit Choice Estimate Results

4.3 Tests of Hypotheses

4.3.1 Cost of Debt and Lenders' Use of Financial Statements

4.3.2 Predictive Ability

5. Robustness Checks

5.1 Supplemental Tests

5.2 Propensity Score Matching

6. Conclusion

45

APPENDICES

BIBLIOGRAPHY 


\section{LIST OF TABLES}

\section{TABLE}

3.1 Sample Selection $\quad 47$

3.2 Distribution of Firms by Industry 48

3.3 Descriptive Statistics 49

3.4 Correlations 50

4.1 Probit Model of Audit Choice $\quad 51$

4.2 Cost of Debt Analysis $\quad 52$

4.3 Cash Flow Prediction Model - Persistence Estimates 54

4.4 Cash Flow Prediction Model - Precision Estimates 55

4.5 Cash Flow Prediction Model with Firm Size Interaction Terms 56

5.1 Propensity Score Matched Sample Descriptive Statistics 57 


\section{LIST OF APPENDICES}

\section{APPENDIX}

A. Variable Definitions 58

B. Bootstrap Test 61 


\begin{abstract}
The Value of Financial Statement Verification in Debt Financing: Evidence from Private U.S. Firms

by

Michael Craig Minnis
\end{abstract}

Chair: Russell Lundholm

I examine how the verification of financial statements influences lenders' debt pricing decisions. To do so, I obtain access to a large proprietary database of privately-held U.S. firms, an important business sector in which the information environment is opaque and financial statement audits are not mandated. I find not only that audited firms have a significantly lower cost of debt, but also that lenders place significantly more weight on audited, compared to unaudited, financial information in setting the interest rate. Further, I provide evidence of a mechanism for this increased financial statement usefulness: accruals from audited financial statements are better predictors of future cash flows. Collectively, I provide novel evidence that audited financial statements are more informative and that this significantly influences lenders' decisions. 


\section{CHAPTER 1}

\section{Introduction}

The verification of financial statements by an independent party is a fundamental aspect of financial reporting. Indeed, financial statement verification is viewed by regulators and exchanges as so vital to the capital allocation process that all firms with publicly traded equity or debt are required to have their financial statements audited by an independent accountant. However, despite the enthusiasm of regulators for financial statement verification and the immense role it plays in the financial reporting process, archival evidence regarding the value of financial statement verification remains mostly elusive. Empiricists examining this issue have been hampered by a key obstacle: the lack of variation in financial statement verification. Because the regulated audit mandate is so pervasive, researchers have had limited access to large sample data with variation in financial statement verification across firms to study the role of an audit - publicly-held firms are required to receive an audit, while privately-held firms without an audit requirement do not disclose their financial statements publicly. 
In this paper I overcome the data availability obstacle by obtaining access to a large proprietary dataset of privately-held firm financial statements. ${ }^{1}$ The firms in this dataset, in contrast to publicly-held firms, do not have a mandated audit requirement. In fact, I find that approximately three-fourths of the firms in my study do not receive financial statement audits, thus providing substantial variation in the extent of financial statement verification. I exploit this variation to understand how and why financial statement verification influences capital providers' decisions. Specifically, because bank financing is a primary source of external capital for privately-held U.S. firms (Berger and Udell 1998), I examine the role of financial statement audits in lenders' debt pricing decisions. To do so, I simultaneously model firms' decisions to receive audits and firms' cost of debt with an endogenous switching model to explicitly account for the endogeneity of the choice of receiving an audit. I find that audited firms enjoy a lower interest rate of 64 basis points, on average, compared to unaudited firms confirming that financial statement verification indeed influences lenders' pricing decisions.

Examining lenders' pricing decisions further, I find that verification does more than simply influence the average level of debt pricing; lenders use audited financial statements more intensively in establishing the interest rate. The role of an audit is to assure financial statement users that the statements are compiled and presented according to Generally Accepted Accounting Principles (GAAP). Thus, verification

\footnotetext{
${ }^{1}$ This extensive dataset is collected from accounting firms and banks throughout the U.S. by Sageworks, Inc., a company that compiles private firm data for benchmarking and credit analysis. For the purposes of this study, Sageworks granted me confidential access to their data which I describe more thoroughly in Section 3.
} 
'hardens' the financial information, making the reports more useful in the debt pricing process (Ijiri 1975, pgs. 33-40). I provide evidence of this hardening role by modeling the cost of debt separately for audited and unaudited firms, explicitly allowing the relation between the cost of debt and the explanatory variables to vary across both sets of firms. I find that lenders' pricing decisions are more sensitive to financial statement variables commonly used in credit analysis (e.g., interest coverage, current ratio, and asset tangibility) when they have been verified. Hence, I provide significant broad-based evidence that audits provide value to lenders and that an audit is not simply a costly signal; the resulting financial statements are more influential in lending decisions.

Having established that verification influences lenders' debt pricing decisions, I next examine a key mechanism underlying why this influence manifests: the ability of the financial statements to predict future cash flows. In determining the quality of a loan applicant, lenders assess the ability of the potential borrower to generate sufficient future cash flows to repay the debt (e.g., Libby 1979; Sinkey 2002, Chapter 10; Maines and Wahlen 2006). Therefore, the predictive ability of the information in the financial statements is of keen importance to lenders and a fundamental characteristic that FASB considers when establishing financial reporting standards (FASB 1978, paragraphs 37-39). The extent to which financial statement assurance ensures compliance with GAAP, then, should enhance the financial statement precision along this vital reporting quality dimension. To investigate this, I compare the relative predictive ability of audited and unaudited financial statements by regressing one yearahead cash flows from operations on contemporaneous net income, separately for 
audited and unaudited firms. I find that the net income of audited financial statements is a better predictor of future cash flows than the net income of unaudited financial statements. I then decompose net income into its cash flow and accrual components and find that the enhanced relation between net income and future cash flows is largely due to the accrual component of income - precisely where auditing should have the most significant impact because of the greater susceptibility to error and manipulation of accruals relative to cash flows.

As the accrual estimation process is intricately linked to the internal controls and accounting expertise of the firm, I extend the predictive ability analysis further by examining cross sectional implications. The auditing benefit to accrual estimation should be amplified in firms with weaker internal accounting capabilities because the external auditor will have incrementally more expertise to enhance the firm's accrual estimation process. To investigate this aspect, I use firm size as a proxy for the extent of internal accounting sophistication and find that the difference in the predictive ability of accruals across audited and unaudited firms is concentrated in smaller firms, indicating that audits serve as a critical substitute for internal firm capabilities. Moreover, I find that the interest rate reduction for audited firms relative to unaudited firms is also greater in these smaller firms suggesting that lenders recognize the expertise substitution effects of an audit for internal accounting capabilities.

Finally, in conducting the analyses in this study it is important to note that, in the U.S. private firm setting, an audit is an endogenous firm choice. Factors that are unobservable to the researcher may affect a firm's decision to receive an audit, the 
lender's use of the financial information, or the firm's reporting quality. Such unobservable factors may include the quality of management or the historical relationship between the firm and the lender. To address this endogeneity concern, I construct an instrumental variable, motivated by regulatory differences across U.S. states, which exogenously affects the supply and demand of auditing services, but is not directly related to the cost of debt or reporting quality. Therefore, I control for potential endogeneity biases using this instrument, which I describe further in Chapter 3. As a robustness check, I also implement a propensity score matching approach which matches audited and unaudited firms on observable characteristics and have similar findings, reinforcing the results.

By providing novel evidence of the value of financial statement verification in debt pricing, this paper makes three significant contributions. First, it contributes to our understanding of the role of audits in the financial reporting and debt financing process. Various studies have highlighted the fundamental importance of verification to financial reporting generally (e.g., Kothari, Ramanna, and Skinner 2010) and to debt financing specifically (Armstrong, Guay, and Weber 2010). I enhance our understanding and provide unique evidence of this notion with a large sample which allows me first to confirm prior findings of a negative relation between verification and the cost of capital (e.g., Blackwell, Noland, and Winters 1998), but more importantly to extend it to provide evidence that not only do lenders place more value on verified financial information, but also that verified financial statements provide higher quality information for lenders in assessing borrowers. 
Second, this paper contributes to our understanding of how privately-held firms - a particularly large and informationally opaque sector of the economy - use and benefit from financial reporting and auditing. Recent studies (e.g., Ball and Shivakumar 2005; Burgstahler, Hail, and Leuz 2006; Allee and Yohn 2009) have begun to shed light on the economic importance of privately-held firms and the uniqueness of their financial reporting environment. However, much of the empirical work investigating how privately-held firms alleviate information opacity issues with lenders focuses on channels such as banking relationships (e.g., Petersen and Rajan 1994, Berger and Udell 1995), not financial reporting. With a significant and unique source of data, I show that financial statement verification plays an important role in the financing process of these firms. In particular, I show that these firms are able to reduce information asymmetry and provide more informative financial data to lenders by subjecting their financial statements to an audit.

Finally, I empirically highlight the distinction between the notions of verifiability (the characteristic that the accounting measure is capable of replication by different measurers) and verification (the actual replication process) of financial information. While verifiability is a desirable financial reporting attribute, the actual act of verification has a substantial impact on how financial statements are used. This distinction is also interesting from a theoretical perspective because the term 'verifiable' is often used synonymously with the term 'contractible.' While most financial information is verifiable, I note that, empirically, lenders recognize the difference 
between information that has the potential to be verified and information which has in fact been verified.

The remainder of the paper proceeds as follows. Chapter 2 provides a discussion of prior literature and formalizes my hypotheses. In Chapter 3 I discuss the private firm setting and my proprietary data. In Chapter 4 I present the main results and in Chapter 5 I present robustness checks. Chapter 6 concludes the paper. 


\section{CHAPTER 2}

\section{Prior Literature and Hypotheses}

In this chapter I discuss the effects of verification on the cost of debt; then I discuss the role of auditing in making financial statements more informative; and finally, I present an important mechanism by which these benefits arise - namely, audited financial statements are better able to predict future cash flows.

\subsection{Auditing and the Interest Rate on Debt}

A significant body of literature examines auditing in the context of its effect on a firm's cost of capital. Theory posits that an audit by an independent party reduces the information asymmetry and moral hazard issues between preparers and users of financial statements. ${ }^{2}$ Hence, audits may reduce informational problems ex ante. Audits may also play an ex post role. Townsend (1979) models the audit as an ex post verification device in the event that a firm defaults on its loan. This costly state verification results in an efficient debt contract. Thus, from a theoretical perspective,

\footnotetext{
${ }^{2}$ See, for example, Jensen and Meckling (1976) and Watts and Zimmerman (1983). Chow (1982) uses an agency framework to investigate the choice of public firms to receive an audit prior to the existence of the Securities and Exchange Commission and the audit requirement. Also see Wallace (2004) for a review of the various roles of an audit.
} 
both ex ante and ex post roles of an audit suggest that verification of financial statements should result in a reduction in the cost of capital for the firm.

The empirical literature examines the relation between financial statement verification and the cost of capital in a number of ways. Because variation in the presence of an audit is generally unavailable, the most prominent approach is to study variation in the characteristics of the auditors. Motivated in part by DeAngelo (1981) who suggests that larger auditors have 'more to lose' in the event of a misreporting problem and, therefore, conduct higher quality audits - prior research uses auditor size as a proxy for audit quality. Using the setting of initial public offerings, Beatty (1989), Willenborg (1999) and Weber and Willenborg (2003) find that initial public offerings (IPOs) associated with larger auditors have less underpricing and that the pre-IPO opinions of the auditors are more predictive of post-IPO stock performance. Research also uses the debt market as a setting to examine the relation between auditor characteristics and the cost of debt. Mansi, Maxwell, and Miller (2004) and Pittman and Fortin (2004) broadly find that the cost of debt is lower for firms with larger auditors.

However, in addition to having to rely on auditor size as a source of audit variation, research examining financial statement verification in a public firm setting is also potentially exposed to complications from alternative information verification channels other than an audit. Specifically, theory suggests that stock price can serve as an aggregator and external verifier of firm information (e.g., Grossman and Stiglitz 1976; Verrecchia 1982; Holmstrom and Tirole 1993; Almazan, Banerji and De Motta 
2008). ${ }^{3}$ Therefore, recent research examines financial statement verification in privately-held firms - where this alternative verification channel does not exist. For example, Blackwell, Noland, and Winters (1998) obtain access to the loan files from two banks and find that firms with an audit receive a 25 basis point reduction in their interest rate. In a current working paper Kim et al. (2007) use a sample of privately-held firms in South Korea which are required to report their financial results publicly and find that audited firms have a 60 basis point lower interest rate on average. ${ }^{4}$ However, it is worth noting that not all studies in this setting find a negative relation between the presence of an audit (or audit quality) and the cost of debt. For example, Fortin and Pittman (2007) fail to find that larger auditors are associated with a lower cost of debt in a sample of large privately-held firms issuing debt to institutional investors. Further, Allee and Yohn (2009, Table 8) examine the survey evidence of the Federal Reserve's National Survey of Small Business Finances and do not find that an audit is associated with a lower interest rate in small privately-held firms.

Thus, theory strongly suggests that the cost of debt is negatively related to the presence of an audit and much of the empirical evidence supports this. However, to provide confirmatory evidence and to reassess the economic magnitude of this relation with a large broad sample of U.S. firms - and because a few studies examining the privately-held firm setting where financial statement verification is the key information verification channel fail to find a relation - I state my first hypothesis as follows:

\footnotetext{
${ }^{3}$ Holmstrom and Roberts (1998) suggest that stock prices play a monitoring role and that they "have a great deal more integrity than accounting-based measures of long-term value" (pg. 89). In the absence of such an instrument, as is the case with private firms, financial statement validation may serve a crucial role to enhance the integrity of the information.

${ }^{4}$ In complementary work, Hope, Thomas, and Vyas (2010) use a World Bank survey of privately-held firms around the world and find that audits reduce managers' perceived financing constraints and costs.
} 
H1: $\quad$ Firms with audits realize a lower cost of debt compared to firms without audits.

\subsection{Increasing Informativeness: The Information Hardening Role of an Audit}

While $\mathrm{H} 1$ considers the average pricing effect of financial statement verification, verification may also have implications for the intensity with which lenders use the financial data in pricing a loan. A primary role of an audit is to assure the user that the reported results are reliable (e.g., Ball 2001; Ball, Jayarman, and Shivakumar 2009). Per FASB's Statement of Financial Accounting Concepts No. 2: "the purpose of verification is to provide a significant degree of assurance that accounting measures represent what they purport to represent" (FASB 1980, paragraph 81).

FASB's notion of verification is intricately related to the theoretical premise of 'hard' and 'soft' information. Petersen (2004) suggests that a key characteristic of hard information is that there is uniform agreement regarding how the information was assembled and how it should be interpreted. Soft information, on the other hand, is subjective - it is based on the perspective of the individual assembling or interpreting the information. As a result, individuals place more weight on the hard information they receive when making decisions because it retains its precision as it is communicated across individuals; in contrast, soft information loses its precision because of the subjectivity in interpreting the information.

This distinction between hard and soft information is precisely the notion of

financial statement verification. Because financial statements are supposed to follow 
general rules in the collection and presentation of the underlying data (i.e., GAAP), they are usually provided as the prototypical example of hard information (e.g., Petersen 2004, pg. 14). However, the definitive role of an audit is to ensure that the financial statement information is materially compiled and presented according to GAAP. Without verification the possibility arises that the individual creating the information (e.g., firm management) may deviate from the generally accepted practice (either through error or manipulation). A third party (i.e., auditor), with both the technical expertise in the generally accepted rules of assembling financial information and the independence to objectively assess the preparer's decisions, may add value by ensuring that the financial statements are in the form expected by the users. ${ }^{5}$ Maines and Wahlen (2006) suggest that the "usefulness of accounting information depends on the degree to which it provides a reliable representation of the relevant economic constructs" (pg. 404). In short, information theory suggests that verification 'hardens' the financial statement information making it more useful to decision-makers. ${ }^{6}$

A particularly relevant empirical question for this study then is, does verification harden financial information for lenders? ${ }^{7}$ In other words, do lenders place

\footnotetext{
${ }^{5}$ Interestingly, in the Financial Executives International's Committee on Private Companies survey of both private firm owners and bank lenders titled, "What do Users of Private Company Financial Statements Want?" a quote by one of the lenders encapsulates both the broad notions of the lenders in the survey and the constructs discussed in this section: "For those companies that do submit audited financial statements, one of the primary advantages we see is that the business must pass a higher level of scrutiny in its reporting process. Where there is an attestation, we assume that the financial statements are more likely to be prepared in a manner consistent with GAAP" (Sinnett and Graziano 2006, pg. 28).

${ }^{6}$ In a recent working paper, Ball, Jayaraman, and Shivakumar (2009) examine a related aspect of an audit, namely the 'confirmation' hypothesis. In this setting, an ex post audit makes management's voluntary disclosures more credible ex ante.

${ }^{7}$ In one of the few examples of related research, Teoh and Wong (1993) use earnings response coefficients to test, and find confirmatory evidence of, the joint hypothesis that larger auditors are associated with more credible financial reports and that investors respond more intensively to more credible reports. Ghicas et al. (2007) examine the value of audit qualifications to financial statement
} 
more weight on the information from audited financial statements? I test the joint hypothesis that audits harden financial information and that lenders recognize this and place more weight on harder financial information in pricing debt. Stated formally:

H2: $\quad$ Financial data from firms with audited financial statements is more highly associated with the firms' cost of debt compared to firms with unaudited financial statements.

\subsection{The Predictive Ability of Financial Statements}

Hypotheses $\mathrm{H} 1$ and $\mathrm{H} 2$ are fundamentally joint hypotheses that 1) audited financial statements are of higher quality (or 'harder') and that, 2) lenders recognize this by offering lower interest rates and using the information more intensively. I now specifically explore the first aspect of the joint hypotheses: do audited financial statements have higher reporting quality for lenders? Or, stated differently, in what sense has the verification made the financial statements harder or more precise? Prior evidence that audits are associated with actual reporting differences generally focus on earnings management qualities and use auditor size as the primary focus of audit variation. For example, Becker et al. (1998) and Francis, Maydew, and Sparks (1999) find that firms with larger auditors have lower levels of manipulated accruals. ${ }^{8}$

users and find that investors impound this information, but underwriters and analysts do not. In addition, significant research, particularly experimental, investigates how management's accounting choices affect financial statement users' perceptions of the information. See Clor-Proell (2009) for a recent study and discussion of this research.

${ }^{8}$ Prior literature has also examined the relation between fees paid to auditors and reporting quality and has found mixed results. For example, Frankel, Johnson, and Nelson (2002) find that there is a positive relation between audit fees paid and earnings management; whereas Larcker and Richardson (2004) find that this relation only holds in a small portion of the sample. 
However, no prior studies have explicitly examined the difference in reporting quality across firms that receive audits and those that do not.

In this study, because I examine how verification affects lenders' actions, I focus on a reporting quality that lenders find particularly relevant - the ability of the financial statement data to predict future cash flows. In making assessments of borrowers, lenders attempt to determine the ability of the firm to repay the loan. To do so, lenders analyze a firm's assets in place (e.g., collateral in the event of default) and cash flow generating ability (Sinkey 2002, Chapter 10). ${ }^{9}$ One of the primary roles of the accounting process, and, in particular accruals, is to help users predict future cash flows (FASB 1978, paragraphs 37-39); while one of the primary roles of the attestation and assurance process is to enhance the reliability of the accounting figures to facilitate this role (Maines and Wahlen 2006). Therefore, if verification enhances the informativeness and reliability of the financial reports (i.e., increases the precision), I expect the net income of audited firms to be a better predictor of future cash flows than the net income of unaudited firms. Stated formally:

H3: The net income of audited financial statements will predict one-year ahead cash flows better than the net income from unaudited financial statements.

\footnotetext{
${ }^{9}$ See Berger and Udell (2006) for an extensive discussion of small and medium size firm financing and the various types of lending in this setting. Also see Armstrong, Guay, and Weber (2010, Section 5) for a more broad discussion of research investigating the use of accounting information in debt contracting.
} 


\section{CHAPTER 3}

\section{Private Firm Setting and Data}

To test my three hypotheses, I use a unique dataset of privately-held firms in the U.S. In this chapter, I describe the setting of privately-held firms and the proprietary dataset.

\subsection{Private Firm Setting}

Privately-held firms are a large, important segment of the U.S. economy. These firms represent over $99 \%$ of all firms and generate over $50 \%$ of the GDP in the U.S. Further, the debt market for these firms is vast: almost $\$ 650$ billion of the $\$ 2$ trillion of outstanding bank financed debt in 2007 consisted of individual business loans of less than $\$ 1$ million (Ou and Williams 2009). ${ }^{10}$ The magnitude of the debt market for these firms is interesting because privately-held firms are remarkably opaque to the public and, hence, must rely on private, unregulated communication with capital providers. Berger and Udell (1998) suggest that "perhaps the most important characteristic defining small business finance is informational opacity" (pg. 616). Despite significant informational problems, these firms are still able to attract

\footnotetext{
${ }^{10}$ The $\$ 650$ billion figure understates the extent of the private firm bank financing as this only includes those loans less than $\$ 1$ million individually. I note in my sample that many privately-held firms have more than $\$ 1$ million in debt.
} 
enormous sums of capital, making this a particularly interesting setting to examine how firms resolve the information asymmetry issues.

Two additional institutional features make these privately-held firms an opportune setting to investigate the role of financial statement verification. First, these firms do not generally face a mandated audit requirement, yet we still observe a demand for auditing from a substantial portion of firms. Thus, I have a sample of otherwise comparable firms except that a portion receive audits, while others do not. Second, because these firms are privately-held, they by definition do not have a publicly traded stock price, which, as discussed in Chapter 2 avoids this alternative information verification channel creating a more powerful setting to identify the effects of financial statement verification.

\subsection{Data Source and Selection}

The data for this study is supplied by Sageworks, Inc., a company that collects private firm data and develops financial analysis tools, primarily for accounting firms and banks. In the process of assessing a client or borrower, accounting firms and banks generally conduct analytical procedures or ratio analyses wherein these financial statement users compare various financial ratios with past performance, budgeted performance and industry peers. ${ }^{11}$ The Sageworks online database was designed to assist accounting firms and banks perform this analysis by providing a convenient interface with industry peer data. In order to conduct the analysis, Sageworks' users

\footnotetext{
${ }^{11}$ Indeed, accounting firms are required to conduct analytical procedures as part of review and audit engagements (Arens, Elder, and Beasley 2005).
} 
input their clients' financial statement data into the system, which then becomes part of the collective dataset. Users of the database only have access to peer firm data at an aggregated level by industry and region. For the purpose of this study, however, Sageworks granted me confidential access to the underlying panel dataset. ${ }^{12}$

The financial data entered into the system consists of income statement and balance sheet items. In addition to financial information, the private firm's industry (NAICS code), legal form, fiscal year-end, state, and type of report (e.g., compilation, review, or audit) are also collected. To ensure data integrity, Sageworks has a team of accounting and programming specialists who examine and monitor the data on a continuous basis.

Table 3.1, Panel A details my sample selection process. I begin with 122,275 firm-years supplied by over 5,000 Sageworks subscribers in all 50 states during the years $2001-2008 .{ }^{13}$ Sageworks has a variety of input screens that its subscribers can select which differ based on the level of detail entered. Nearly half of the observations were entered using an abbreviated input screen, which has insufficient detail to calculate the interest rate or cash flows, so I delete these firm-years. ${ }^{14} \mathrm{I}$ also delete observations from the Utilities, Finance, and Insurance industries because firms in these industries may

\footnotetext{
${ }^{12}$ While this is a panel dataset, I note that changes in verification level within a firm across time are very infrequent; thus, unfortunately, I have insufficient data to conduct fixed effects or difference-indifference analyses.

${ }^{13}$ To my knowledge, there are no particular criteria required for inclusion in this database other than the private company must be a client of a subscribing accounting firm or bank. Note that there are over 200,000 firm-year observations initially and I eliminate firms that report on a cash basis, submit the information via tax return, do not engage an accounting firm (e.g., submit company prepared financial statements), have missing data, or are not based in the United States. The initial 122,275 firm-years are only those observations which have the financial statements compiled, reviewed, or audited on an accrual basis of accounting.

${ }^{14}$ Note that the abbreviated report observations indicate whether the financial data has been audited, so I still use these deleted observations in calculating the instrumental variable as described in Section 3.3 below.
} 
face various mandated reporting regulations which likely affect their financial statement verification decisions. Next, I eliminate firm-years with extreme observations. These include firm-years in which net income (NI), cash flow from operations (CFO), Accruals, or property, plant and equipment (PPE) are greater than the balance of total assets at year-end (see Appendix A for variable definitions). I also eliminate firm-years in which Sales change by a factor of 2 (i.e., increase by more than $100 \%$ or decrease by more than $50 \%$ ) or have total liabilities which are more than twice the year-end total assets. ${ }^{15}$ Finally, to ensure that a comparable unaudited firm exists for each audited firm, I eliminate any audited firms with total assets greater than the largest unaudited firm of $\$ 259$ million. After the filtering procedures, 55,206 firm-year observations remain. The regression analyses require one-year ahead interest rates or cash flows, so I eliminate firm-years without at least 2 consecutive years of data, leaving 26,005 firmyear observations eligible for the regression analyses. Panel B of Table 3.1 provides the distribution of these firm-years by assurance level over time. The initial years have fewer observations as the result of fewer subscribers during the dataset start-up phase; whereas the decrease in 2007 is the result of the timing of data entry when I received the data from Sageworks.

To provide a broad perspective of the firms in the dataset, in Table $3.2 \mathrm{I}$ present the distribution of the firms across industries and compare this distribution to 1) all firms in the U.S. (as reported by the NAICS Association) and, 2) the publicly-held firms covered by the Compustat dataset. Relative to the publicly-held firms in the

\footnotetext{
${ }^{15}$ I use these cutoff values to ensure that extreme values are not driving the results. Nevertheless, I also use cutoff points of 2 times assets and sales growth of a factor of 3 and the results are very similar.
} 
Compustat dataset, the distribution of my sample of privately-held firms more closely represents the distribution of all firms in the U.S. In particular, $67 \%$ of Compustat firms are in Manufacturing, Information, and Finance and Insurance, while this represents only $8 \%$ of the total population of firms and only $24 \%$ of the privately-held firms in my sample. Still, Manufacturing and Construction are somewhat over represented in the Sageworks dataset relative to the entire population of U.S. firms.

\subsection{Variable Definitions and Descriptive Statistics}

I now discuss the construction of each of the variables used throughout the analyses and their descriptive statistics. Table 3.3 presents the statistics both unconditionally (Panel A) and conditional on audit level (Panel B). Appendix A provides further detail of the calculation for all variables used in my analysis.

Attestation Level: Firms have the choice of three levels of financial statement attestation: compilation, review, or audit. The three levels of verification differ with regard to the degree of assurance provided by the outside accountant as to the accuracy of the financial statements (Arens, Elder, and Beasley 2005). Compilations provide no assurance on the account balances; reviews provide only negative assurance; audits provide positive assurance. Table 3.3, Panel A reveals that almost one quarter of the sample receives an audit, with the remaining firms receiving either a review or compilation. Thus the sample has both a substantial number of firms receiving audits, and a substantial number of firms without audits to serve as comparisons. 
Interest Rate: The dependent variable in the cost of debt analysis is the firm's average interest rate on debt. The interest rate is not provided directly in the dataset, so I estimate it by dividing the reported interest expense by the average of the beginning and ending debt levels. Prior studies which also use this approach to calculate interest rates (e.g., Pittman and Fortin 2004; Francis et al. 2005) note that this measurement approach contains significant noise, so I follow their approach and truncate the variable at the $5^{\text {th }}$ and $95^{\text {th }}$ percentiles. Even after truncating at the $95^{\text {th }}$ percentile, I note that the interest rate for some firms exceeds the prime interest rate for the year by a large amount, so I further truncate observations more than 1,000 basis points over the prime rate for the year. As shown in Table 3.3, Panel A, the mean interest rate for the sample is $7.3 \%$ with a median of $7.0 \% .{ }^{16}$

Financial Statement Ratio Variables: I use three financial performance variables typically used by lenders in assessing borrowers. I calculate Interest Coverage as earnings before interest, taxes and depreciation (EBITDA) divided by interest expense as a measure of the firm's ability to service the debt from its operations. Table 3.3 indicates that firms generate EBITDA 6.8 times greater than their interest expense, on average. ${ }^{17}$ Current ratio, defined as current assets divided by current liabilities, measures the level of firm resources to service obligations which will occur over the next year and

\footnotetext{
${ }^{16}$ To provide a check on my interest rate estimation approach, the calculated average rate in my sample is very similar to the reported sample average of $6.6 \%$ in Allee and Yohn (2009, Table 1) who report the interest rates of surveyed U.S. private firms. A potential reason for the slightly higher interest rate in my sample is that the Allee and Yohn (2009) data is exclusively from the years 2003-2004 which had low prime interest rates relative to other years in my sample which includes data from 2001-2008, with a majority of my sample in the post-2004 years. See additional discussion in Appendix A.

${ }^{17}$ Upon examination of the Standard \& Poors' credit rating report for publicly-held firms, I note that the Interest Coverage value of 6.8 places the average firm in my sample between the BBB and BB credit ratings (near the investment grade/junk bond threshold) (Lugg 2008).
} 
has a mean of 2.5 in my sample. ${ }^{18} \mathrm{PPE}$, defined as net property, plant and equipment divided by total assets, is the extent of tangible assets in place that could be liquidated to repay outstanding debts in the event of default. Approximately $32 \%$ of firm assets in the sample consist of PPE according to Table 3.3.

Firm Characteristic Controls: I now discuss other control variables used in modeling both the choice of receiving an audit and the cost of debt. Again, the summary statistics are reported in Table 3.3. Calculating Leverage as total liabilities divided by total assets, I note that the privately-held firms are highly leveraged, as liabilities are approximately two-thirds of the total assets, on average. ${ }^{19}$ To allow for any unique features of firms with negative equity positions, I also include an indicator variable, Neg Equity, which equals one if total liabilities exceed total assets. The firms in my sample are typically small, compared to publicly-held firms in the Compustat database, as Table 3.3 reports that the average (median) firm has $\$ 6.5$ (\$2.6) million in total assets. Table 3.3 also reports the descriptive statistics for the natural log of total assets (LN(Assets)), which is the firm size variable I use in all analyses. I also control for firm growth using Sales Growth, which is the year-over-year percentage growth in revenues. The average firm is growing at about $8 \%$ per year. Finally, because firms which file under Subchapter C of the Internal Revenue Code are likely older and more sophisticated than firms with other forms of organization (e.g., sole proprietorships, partnerships, limited liability companies), I create an indicator variable, C-Corp, which

\footnotetext{
${ }^{18}$ In untabulated results, I also use Working Capital [(current assets - current liabilities)/total assets], which by definition is distributed between 0 and 1 , and inferences are unchanged.

${ }^{19}$ As a point of reference, the Compustat set of firms has a leverage ratio of approximately $55 \%$ using the same calculation and time frame as the dataset I use in this study. In untabulated results, I also calculate Leverage excluding accounts payable from total liabilities and inferences are unchanged.
} 
equals 1 if the firm is a C-corporation (zero, otherwise) to capture these potential effects. $^{20}$

Exogenous Instrument: Receiving an audit is a firm-level choice and, therefore, may be endogenously determined with the cost of capital and reporting quality, biasing coefficient estimates and confounding inferences. To account for the endogeneity, I employ an endogenous switching model which requires an exogenous instrument - a variable that is related to the firm's decision to receive an audit, but is not directly related to the cost of debt or reporting quality. In constructing this instrument, I exploit differences in regulations across states which exogenously affect both the supply and demand for attestation services. For example, one way in which state regulation affects the supply of attestation services is via the licensure of Certified Public Accountants (CPAs). The requirements for licensure are state level decisions and vary across states. ${ }^{21}$ In addition, states have differing regulations for private firms which may result in exogenous differences in the demand for accounting services. For example, taxation of businesses (e.g., income, gross receipts, and property taxes) varies by state and the degree of complexity likely impacts the demand for and supply of attestation services. $^{22}$

\footnotetext{
${ }^{20}$ Ribstein (2007) finds a significant trend away from selecting C-corporation status for start-up firms, therefore, C-Corp firms are likely older. Also note that C-Corp firms are the only form of organization in my dataset which pays taxes at the entity level. All other forms of organization are so-called "flowthrough" entities that file income taxes, but all income is taxed at the individual owner (i.e., partner, member or shareholder) level.

${ }^{21}$ Examples of differences in regulations between the states include: 1) whether CPA exam applicants are required to have a minimum of 150 university credit hours; 2) whether states recognize the license of CPAs from other states with minimal paperwork (known as reciprocity); and 3) the number of years of experience required prior to granting licensure (Arens, Elder, and Beasley 2005).

${ }^{22}$ For example, firms in high tax complexity states may be more likely to engage a CPA for compliance reasons which may lead to additional attestation services (affecting demand) (O'Sullivan 2009).
} 
I proxy for a state's attestation regulatory environment by calculating the percentage of firm-years with audits for each state (State Audit). This variable assumes that the probability of choosing an audit across firms within a state is related to the exogenous regulatory environment of that state, but is unrelated to outcome measures such as interest rates or accounting quality. To capture the most complete assessment of the attestation environment within the state, I construct this variable before eliminating those firm-years with insufficient data or extreme values. ${ }^{23}$ The average (median) state has 2,398 $(1,750)$ firm-year observations, ensuring that a particular firm has little individual influence on this variable. Table 3.3 reports that the mean (median) of this variable is $18.4 \%(17.9 \%)$.

While State Audit is constructed to measure state effects with respect to the attestation environment, one potential concern - particularly related to the cost of debt analysis - could be that the variable is also correlated with a state's banking environment. By creating a state-level measure of the extent of banking regulation, Rice and Strahan (2008) show that interest rates are correlated across firms within a state as a result of banking regulatory conditions. Therefore, State Audit, which is measured at the state level, may also be correlated with the state banking regulation environment and, hence, a firm's interest rate. To mitigate any concerns that State Audit is also identifying banking regulatory issues, I include Rice and Strahan's (2008) measure of the level of banking regulation within a state in all analyses. The Branching Restriction

\footnotetext{
${ }^{23}$ This calculation is based on the 122,275 firm-year observations reported in the first row of Table 3.1. Recall that the abbreviated report firm-years were deleted because of inadequate financial variables, though they still report the level of attestation. I also construct the instrumental variable only including the final selection of firms and the inferences do not change.
} 
Index $(B R I)$ is a discrete valued variable (with values between 0 and 4 , inclusive) representing the number of bank branching restrictions within a state. ${ }^{24}$ See the description in Appendix A for additional detail.

Cash Flow Predictive Ability Variables: I calculate three additional variables needed for the cash flow predictive ability analysis. First, on average the firms in the sample are profitable with an NI (net income divided by total assets) of $7.4 \%$. This consists of an Accruals portion, which on average is negative, and a cash flows (CFO) portion, which on average is positive. Note that the dataset does not include cash flow statement data, so I calculate Accruals following Sloan (1996) using the changes in working capital accounts less depreciation and amortization (see Appendix A). I then calculate $\mathrm{CFO}$ by subtracting Accruals from reported net income. Both Accruals and CFO are scaled by year-end total assets.

Finally, it is worth noting the differences between audited and unaudited firms. Panel B of Table 3.3 reports selected statistics conditional on financial report attestation level. The most distinct difference in firms across attestation levels is firm size. Firms that receive audits are nearly three times the size of firms that do not, on average. Firms with audits also have higher Leverage and lower Interest Coverage, yet lower Interest Rates. This suggests that firms with audits have lower interest rates, but that these differences may be related to other observable and unobservable firm characteristics which need to be controlled for in a multivariate setting which I conduct in Chapter 4.

\footnotetext{
${ }^{24}$ As an additional test to ensure that that the economic environment of each state is not jointly affecting interest rates and audit choices, I also include gross domestic product growth for each state over the sample time period with no change to the results.
} 


\subsection{Correlations}

As an additional examination of the relation between the variables at a univariate level, I present the pairwise Pearson correlations among the variables in Table 3.4. Consistent with the descriptive statistics in Panel B of Table 3.3, an audit is positively associated with firm size and Leverage, but negatively associated with Interest Coverage and Interest Rates. The correlations among other variables are generally consistent with expectations and prior studies. 


\section{CHAPTER 4}

\section{Empirical Approach and Results}

\subsection{Self Selection Bias and Estimation Issues}

To assess the effects of financial statement verification on interest rates, in the experimental ideal I would randomly assign audits to firms; then using standard OLS estimation, I would model the interest rate $\left(Y_{i}\right)$ as:

$$
Y_{i}=X_{i} \beta+\alpha A_{i}+\varepsilon_{i}
$$

where $X_{i}$ is a vector of exogenous observable factors affecting firm i's interest rate, $\beta$ is a vector of parameters measuring the impact of those factors on interest rates, and $A_{i}$ is an indicator variable which equals 1 if the firm receives and audit and 0 otherwise. Thus, $\alpha$, the coefficient on $A_{i}$, measures the 'average treatment effect' (ATE) of the audit on interest rates conditional on the observable factors $\left(X_{i}\right)$. Unfortunately, financial statement verification is a firm choice, not a random assignment. As a result, if unobservable factors affecting a firm's choice of audit are correlated with unobservable factors affecting the firm's interest rate, then $X_{i}, A_{i}$, or both would be correlated with the error term, $\varepsilon_{i}$, resulting in selection bias in the estimates of $\beta$ and $\alpha$ (Francis and Lennox 2008). For example, if managers with high ability demand the 
services of an outside audit, and at the same time lenders offer lower interest rates to managers with high ability then the estimate of $\alpha$ is inflated if the manager's ability is not captured in $X_{i}$. Alternatively, if lenders more frequently demand audited financial statements from new borrowers (compared to borrowers with which they have a lengthy relationship), and new borrowers also receive higher interest rates, then the estimate of $\alpha$ is attenuated.

I employ an endogenous switching model in order to address the selection bias issue and consistently estimate the model parameters (see Maddala 1983, Chapters 8 and 9). ${ }^{25}$ Under this approach, the model sorts firms into one of the two observable regimes: audited or unaudited. This switching equation takes the following general form:

$$
A_{i}^{*}=Z_{i} \pi+u_{i}
$$

where $A_{i}^{*}$ is a latent variable representing the firm's benefit from receiving an audit and $Z_{i}$ is a vector of explanatory variables affecting firm i's decision to receive an audit. Because $A_{i}^{*}$ is unobservable, I estimate the equation using $A_{i}$ which, as defined previously, is an indicator variable which equals 1 whenever the firm's net benefit of an audit is positive (i.e., the firm receives an audit), and 0 otherwise (i.e., the firm is unaudited). The switching model then consists of a system of three estimable equations which includes the switching equation and two outcome equations - one for unaudited firms and one for audited firms:

25 See Bharath, Sunder, and Sunder (2008) for another recent example of this approach in the accounting literature. 


$$
\begin{aligned}
& A_{i}=Z_{i} \pi+u_{i} ; \\
& Y_{0, i}=X_{i} \beta_{0}+\varepsilon_{0, i} \text { if } A_{i}=0 \text { (i.e., unaudited); and } \\
& Y_{1, i}=X_{i} \beta_{1}+\varepsilon_{1, i} \text { if } A_{i}=1 \text { (i.e., audited). }
\end{aligned}
$$

Again, $Z_{i}\left(X_{i}\right)$ is the vector of factors affecting firm i's audit choice (interest rate). The vector $Z_{i}$ includes all the variables in $X_{i}$ as well as a variable appropriately excluded from $X_{i}-$ an instrument - which is associated with the firm's choice to receive an audit but is not directly associated with the firm's interest rate. As discussed in Chapter 3, I include State Audit as this exogenous instrument. $\pi, \beta_{0}$ and $\beta_{1}$ are the vectors of parameters to be estimated.

Endogeneity (i.e., selection bias) arises when the error term in the switching equation is correlated with the error terms in the outcome equations and this correlation is not addressed. The endogenous switching model approach resolves this issue by first making the assumption that the three error terms $\left(u_{i}, \varepsilon_{0, i}\right.$ and $\left.\varepsilon_{1, i}\right)$ have a trivariate normal distribution and then simultaneously estimating equations (3), (4), and (5) by maximum likelihood. This technique thus eliminates estimation bias in the coefficients by explicitly accounting for, and estimating, the potential correlation across the error terms. ${ }^{26}$

\footnotetext{
${ }^{26}$ Note that an alternative endogenous switching model approach to maximum likelihood estimation is the so-called two-step procedure which: 1) estimates equation (2) as a probit model and derives the inverse Mills ratio from the fitted values of $A_{i}$; and then, 2) includes the calculated inverse Mills ratios in equations (3) and (4) to account for the unobservable factors affecting both the decision to receive an audit and the interest rate. This approach has the advantage that it does not place as much reliance on the normality distributional assumption, but has the disadvantage of being less efficient if the normality assumption holds (see Puhani 2000). In untabulated results, I use this procedure and the results are very similar, both economically and statistically.
} 
In addition to the endogeneity concern, the model established in equations (3), (4), and (5) also addresses a second issue with estimating equation (1): it forces the estimates of the $\beta$ parameters to be identical for both unaudited and audited firms. If my Hypothesis 2 is correct and lenders use firm information differently based on the presence of an audit, then the $\beta$ vector of parameters needs to be estimated separately for both groups of firms. By estimating separate interest rate outcome equations for unaudited and audited firms (equations 4 and 5, respectively), the endogenous switching model relaxes this restriction and allows me to directly compare the magnitudes of $\beta_{0}$ and $\beta_{1}$ as a test of $\mathrm{H} 2$.

\subsection{Modeling the Audit Choice}

In this section I first discuss the predicted relations between the audit choice and the explanatory variables and then I present the results. Note that while the choice to receive an audit is simultaneously estimated with each of the analyses in later sections (i.e., interest rate and cash flow predictability), for brevity I only discuss the audit choice model and results in this section.

\subsubsection{Variables Predicting Audit Choice}

State Regulatory Environment: As discussed in Chapter 3, section 3, a firm's audit choice is likely affected by the regulatory environment of the state in which it operates. Therefore, I predict a positive association between State Audit and the firm's 
choice to receive an audit. I also include the Branching Restriction Index (BRI) to account for the banking regulatory environment of the state.

Profitability and Liquidity: A firm's debt service capability (as measured by Interest Coverage) and liquidity (as measured by Current Ratio) may have two counteracting relations with attestation level. First, firms that have significant interest service capability and liquidity may both have the resources to pay for an audit and also want to ensure lenders that the high profit and liquidity levels are the result of true firm performance and not report manipulation. In contrast, lenders may be more concerned about the default risk of low performance firms. Therefore, firms with lower coverage and liquidity may receive audits in order to attract capital. ${ }^{27}$ Given the competing explanations, I do not make a prediction on the direction of the relation for either coverage or liquidity.

Fixed Assets: Borrower-lender agency conflicts may arise when a borrower's assets are very liquid (such as cash). When a firm is nearing default, an owner-manager can liquidate and expropriate the firm's assets, leaving an empty shell for the creditors (Dyck and Zingales 2004). Assets such as property, plant, and equipment may reduce the ability of management to inappropriately transfer assets from the debt holders to themselves because tangible assets are less liquid and more easily identified. Therefore,

\footnotetext{
${ }^{27}$ The two potential relations between firm performance and audit choice are articulated by the signaling and monitoring hypotheses of auditing, respectively. Signaling hypotheses suggest that 'good' type firms receive audits in order to credibly reveal their private information, while 'bad' types are unable to mimic (see, for example, Titman and Trueman 1986; Datar, Feltham, and Hughes 1991). The monitoring role of auditing suggests that firms with poor performance may receive the most benefit from committing to an audit by an independent party because an audit reduces moral hazard concerns.
} 
firms with higher levels of property, plant, and equipment may receive less benefit from outside monitoring because of the illiquidity and collateral value of the assets.

Leverage: In contrast to fixed assets, leverage is positively associated with debtrelated agency conflicts because owners with little equity have greater incentives to engage in asset substitution; that is, they identify high-variance, negative NPV projects to the detriment of lenders (Jensen and Meckling 1976). Therefore, owners of highly leveraged firms have incentives to commit to monitoring. Alternatively, firms with a high degree of leverage may be viewed as a significant risk to auditors, who may, in turn, decline the audit engagement, creating a negative relation (Johnstone 2000).

Size: Larger firms are likely to face more significant agency conflicts and, hence, have a greater need for monitoring (Jensen and Meckling 1976, Watts 1977, Watts and Zimmerman 1986). Manager-owner separation and shareholder dispersion is more likely in larger firms, creating a need by the owners to verify the financial reports of the professional management. Lenders also demand more monitoring from larger firms because of larger loan sizes and the resulting additional opportunities for asset substitution. Increased agency conflicts may also arise within a larger firm. The CEO is further removed from operations and must rely on information from subordinates and, therefore, may desire higher levels of attestation to ensure that the financial statements upon which she is basing decisions are accurate. ${ }^{28}$ As monitored financial statements mitigate agency conflicts, I expect the level of attestation to be increasing in firm size. ${ }^{29}$

\footnotetext{
${ }^{28}$ Stein (2003) notes that "within firm" capital allocation, whereby the CEO decides which projects will receive investment, is susceptible to agency conflicts between the CEO and subordinates who propose projects (and request capital). Attested financial statements may reduce these internal agency conflicts similarly to the reduction in external (e.g., manager-shareholder) agency problems. Waymire (2009) views
} 
Growth: Firm growth is likely associated with the number of investment opportunities. Investment opportunities create a demand for higher quality financial information to facilitate both internal capital allocation decisions and external capital acquisition. I therefore predict that growth is positively associated with attestation level.

Incorporation Status: As discussed in Chapter 3, section 3, C-corporations are likely more sophisticated than other firms. They are permitted to have any number (and classes) of shareholders and have more rigorous filing requirements than other legal forms (Dixon et al. 2006). The level of firm sophistication is likely positively associated with the level of attestation. Therefore, attestation level may be higher for Ccorporations than other legal forms.

To summarize, I estimate the choice of attestation with the following probit model, including Industry and Year indicators to capture fixed effects related to specific industries and years:

$$
\begin{aligned}
\text { Audit }_{i, t}= & \pi_{0}+\pi_{1} \text { State_Audit }_{i, t}+\pi_{2} \text { InterestCoverage }_{i, t}+\pi_{3} \text { CurrentRatio }_{i, t}+\pi_{4} \text { PPE }_{i, t} \\
& \left.+\pi_{5} \text { Leverage }_{i, t}+\pi_{6} \text { NegEquity }_{i, t}+\pi_{7} \text { LN}_{\text {(Assets }}\right)_{i, t}+\pi_{8}{\text { Sales } \text { Growth }_{i, t+1}} \\
& +\pi_{9} \text { CCorp }_{i, t}+\pi_{10} \text { BRI }_{i, t}+\sum_{j=11}^{18} \pi_{j} \text { Industry }_{i, t}+\sum_{y=19}^{22} \pi_{y} \text { Year }_{i, t}+u_{i, t} .
\end{aligned}
$$

this perspective of financial statements as "the fundamental demand for accounting" (pg. 53) - high quality financial data for better decision-making.

${ }^{29}$ In considering the hypothesized association between firm size and attestation level, the costs of financial statement production and attestation also need to be considered. The association between firm size and audit costs is an increasing, but concave function of firm size (see, for example, Blackwell, Noland, and Winters 1998, Table 6). Therefore, the cost may be more burdensome for smaller firms, again suggesting a positive association between firm size and attestation level. 


\subsubsection{Audit Choice Estimate Results}

Table 4.1 presents the results of the probit model explaining attestation level choice. First note that the estimated coefficient on State Audit is highly significantly positive, mitigating a weak instruments concern. ${ }^{30}$ Second, the estimated coefficients on several of the firm characteristic variables are consistent with predictions. Attestation level is significantly increasing in Neg Equity (though insignificantly related to Leverage), LN(Assets), and C-Corp. However, the coefficients on two of the variables are not significant in the direction predicted. The coefficient on Sales Growth is positive as predicted, but not significant, while the coefficient on PPE is actually positively significant. ${ }^{31}$ The coefficients on Interest Coverage and Current Ratio are insignificantly positive.

\subsection{Tests of Hypotheses}

\subsubsection{Cost of Debt and Lenders' Use of Financial Statements}

In H1 I predict that the cost of debt is lower for firms with financial statement audits compared to firms without audits; and, in H2 I predict that the interest rates of audited firms will be more sensitive to financial statement variables compared to unaudited firms. To test these hypotheses, I use the following equation to model the firm's average interest rate:

$$
\text { InterestRate }_{i, t+1}=\beta_{0}+\beta_{1} \text { InterestCoverage }_{i, t}+\beta_{2} \text { CurrentRatio }_{i, t}+\beta_{3} P P E_{i, t}
$$

\footnotetext{
${ }^{30}$ I also note that the instrument has a significant partial $\mathrm{R}^{2}$ of $2.3 \%$.

${ }^{31}$ This finding may be the result of the collateral value of PPE - i.e., firms with significant amounts of PPE may use these assets as collateral on the loans. In turn, the lenders may request that the asset existence and valuation be verified by an audit.
} 


$$
\begin{aligned}
& \left.+\beta_{4} \text { Leverage }_{i, t}+\beta_{5} \text { NegEquity }_{i, t}+\beta_{6} \text { LN(Assets }\right)_{i, t}+\beta_{7} \text { SalesGrowth }_{i, t+1} \\
& +\beta_{8} \text { CCorp }_{i, t}+\beta_{9} \text { BRI }_{i, t}+\sum_{j=10}^{17} \beta_{j} \text { Industry }_{i, t}+\sum_{y=18}^{21} \beta_{y} \text { Year }_{i, t}+u_{i, t} .
\end{aligned}
$$

Recall from Chapter 4, section 1 that I estimate equation (8) separately for audited and unaudited firms (i.e., equation (8) is analogous to equations (4) and (5) in the model of Chapter 4, section 1) and simultaneously with the choice to receive an audit (i.e., equation (7)) by maximum likelihood.

Table 4.2, Panel A reports the results of estimating the endogenous switching model. $^{32}$ First, note from Panel A that the signs on each of the coefficients are consistent with expectations and prior studies, with the exception of Leverage and Neg Equity. ${ }^{33}$ Interest Rate is decreasing in Interest Coverage, Current Ratio, PPE, LN(Assets), and C-Corp. Focusing on the three financial statement analysis variables, I find that the estimated coefficients are significantly more negative for the audited firms compared to the unaudited firms. Indeed, these differences are economically significant as well. Ceteris paribus, a one standard deviation increase in Interest Coverage, Current Ratio, or PPE results in a 16, 16, or 39 basis point larger decrease Interest Rate for audited

\footnotetext{
${ }^{32}$ The results of estimating equation (7) in the system of equations are similar to those in Table 4.1 and are not shown for brevity.

${ }^{33}$ The negative relation between leverage and interest rate has been found in prior papers as well, such as Francis et al. (2005, Table 2). In considering this issue, I note two observations: 1) Francis et al. (2005) also use Interest Coverage as an explanatory variable as I do in Table 4.2; and 2) Interest Coverage and Leverage have a relatively high negative correlation in my sample of -0.41 . To investigate potential concerns that collinearity between Interest Coverage and Leverage is causing unstable estimates of the coefficients, I calculate an alternative measure of profitability as Net Profit before Taxes and Depreciation divided by Sales. This profitability measure has a univariate correlation with Leverage of only -0.04 , which is substantially less than univariate correlations of Interest Coverage or NI with Leverage, as shown in Table 3.4. In untabulated results, I use this alternative profitability measure and find that coefficients on Leverage and Neg Equity are not significantly different from zero in the unaudited firms and Leverage is significantly positive for the audited firms. However, the coefficient on Neg Equity remains significantly negative for the audited firms. All other inferences remain using this alternative profitability measure.
} 
compared to unaudited firms, respectively. This provides significant support of $\mathrm{H} 2$ that the interest rate is more sensitive to the financial information of audited firms.

$\mathrm{H} 1$ predicts that the treatment effect of an audit is to reduce the interest rate on debt. I directly estimate this impact using the estimated parameters of the model to derive predicted outcomes for each firm under each regime. ${ }^{34}$ I then calculate the ATE as the difference in the predicted interest rates for each firm in both regimes averaged over the entire sample: ${ }^{35}$

$$
A T E=\frac{1}{N} \sum_{i=1}^{N}\left(X_{i} \hat{\beta}_{1}\right)-\frac{1}{N} \sum_{i=1}^{N} X_{i} \hat{\beta}_{0} .
$$

Panel B of Table 4.2 reports the ATE calculations as described by equation (9). The unconditional results show that an audit significantly lowers the interest rate on debt by 64 basis points. To indicate the economic magnitude of this difference, the average firm in the interest rate regression sample has approximately $\$ 3.6$ million of debt. A 64 basis point reduction in the annual interest rate on this debt amounts to approximately $\$ 23,000$ in annual interest savings, which is equivalent to approximately $6 \%$ of the average firm's net profit before tax. ${ }^{36}$

\footnotetext{
${ }^{34}$ See Shehata (1991) for an example of this approach and Maddala (1991) for a discussion.

${ }^{35}$ Note that this is precisely the same formula that would result in $\alpha$ as an estimate of the ATE in the simple model of equation (1). In that case, because the $\beta$ s are assumed to be the same for unaudited and audited firms, these would be eliminated from equation (9) and the $\alpha$ estimate would remain. Averaging over the entire sample would simply result in the estimate of $\alpha$. The average treatment effect on the treated (ATT) and the average treatment effect on the untreated (ATUT) can be similarly calculated by averaging over the respective samples only. As expected with rationally behaving firms, the ATT is larger (115 basis points) than the ATUT (48 basis points).

${ }^{36}$ I also note that, based on the cost data from Blackwell, Noland, and Winters (1998), Table 6, and my own discussions with a CPA firm, the average sample firm would face audit costs of approximately $\$ 15,000-\$ 25,000$. Therefore, the interest rate savings may completely offset the external cost of an audit (i.e., not considering internal firm costs, management time, etc.) and very likely more than offset the incremental cost of an audit over and above the cost of a review, which can be $30 \%-60 \%$ of the cost of an audit.
} 
To summarize results from Table 4.2, I find that firms with audits enjoy lower interest rates and that lenders' debt pricing decisions are more sensitive to the information from the financial statements. I conclude that this provides substantial evidence in support of $\mathrm{H} 1$ and $\mathrm{H} 2$.

\subsubsection{Predictive Ability}

H3 predicts that audited financial statements are of higher quality for lenders' decision-making in determining the borrowers' ability to service the loan in the future. To test this hypothesis, I consider two measures: 1) the extent to which current reported performance is associated with future cash flows (which I call 'persistence'); and 2) the relative explanatory power of current performance for future cash flows (which I call 'precision'). Specifically, I use the empirical approach of Barth, Cram, and Nelson (2001) to examine the relative ability of net income, and its components, to predict future cash flows across audited and unaudited firms. The measures of interest are the magnitudes of the estimated coefficients (persistence) and the $\mathrm{R}^{2}$ (precision) from the regression of one-year ahead cash flow from operations $\left(\mathrm{CFO}_{i, t+1}\right)$ on combinations of current year net income $\left(\mathrm{NI}_{i, t}\right)$, cash flow from operations $\left(\mathrm{CFO}_{i, t}\right)$, and Accruals $s_{i, t}$ all scaled by year-end Total Assetsi, ${ }^{37}$ I begin by examining the magnitude of the relation between future cash flows and net income in the following regression:

\footnotetext{
${ }^{37}$ Two items are worth noting regarding my use of terminology: 1) Because I use future cash flows as the dependent variable, I am using the term net income 'persistence' admittedly somewhat loosely. More precisely, persistence of net income models future net income as the dependent variable (see, for example, Richardson et al. 2005 and Dichev and Tang 2009). However, based on the lending literature in which lenders' objective is to predict future cash flows, this is the dependent variable I choose to examine. Nevertheless, in untabulated results I also use future Net Income $\left(\mathrm{NI}_{i, t+1}\right)$ rather than future cash flows in all tests in this section and the inferences are the same; and 2) I am using the term 'precision'
} 


$$
C F O_{i, t+1}=\varphi_{0}+\varphi_{1} N I_{i, t}+\sum_{j=2}^{9} \varphi_{j} \text { Industry }_{i, t}+\sum_{y=10}^{13} \varphi_{y} \text { Year }_{i, t}+v_{i, t}
$$

As in the analysis of interest rates in the previous section I use the endogenous switching model (with the audit choice equation (7)) to estimate the parameters of equation (10) for both audited and unaudited firms separately and simultaneously with the audit choice model. The magnitude of the difference of the coefficients on $\mathrm{NI}_{i, t}$ across the audited and unaudited firms is the statistic of interest to examine persistence. Table 4.3, Panel A, reports that $\mathrm{NI}_{i, t}$ for both unaudited and audited firms is highly positively associated with $\mathrm{CFO}_{i, t+1}$; however, as the difference column indicates, the magnitude of the relation of $\mathrm{NI}_{i, t}$ for the audited firms is significantly higher.

As prior research highlights that cash flows are more persistent than accruals (e.g., Richardson et al. 2005), the difference in Panel A between unaudited and audited firms may be the result of more persistent cash flows underlying the net income. If this is true, this may not necessarily be the result of financial statement verification, but rather differences in underlying business fundamentals. To examine this potential explanation, I decompose $\mathrm{NI}_{i, t}$ into its two components - $\mathrm{CFO}_{i, t}$ and Accruals $_{i, t}-$ and estimate the following regression:

$$
C F O_{i, t+1}=\varphi_{0}+\varphi_{1} C F O_{i, t}+\varphi_{2} \text { Accrual }_{i, t}+\sum_{j=3}^{10} \varphi_{j} \text { Industry }_{i, t}+\sum_{y=11}^{14} \varphi_{y} \text { Year }_{i, t}+v_{i, t}
$$

whereas past literature has used the term 'predictability' for the same empirical measure that I use (e.g., Francis et al. 2004). However, because I view both the magnitude of the relation between future cash flows and current performance (i.e., the estimated persistence coefficient) and the precision of the estimate (the $\mathrm{R}^{2}$ from the regression) as contributing to the predictive ability of the financial statements, I do not use the term predictability for the $\mathrm{R}^{2}$ measure to avoid confusion. 
Panel B of Table 4.3 reports the results and I find that both $\mathrm{CFO}_{i, t}$ and Accruals $s_{i, t}$ are more persistent for audited firms, but that the difference in the Accruals ${ }_{i, t}$ persistence is twice the magnitude of the difference in $\mathrm{CFO}_{i, t}$ persistence. In sum, I find that the magnitude of the relation between the components of net income and future cash flows is higher for audited firms, suggesting that current period net income may be more informative to lenders in predicting next year's cash flows when the financial statements have been verified.

While the magnitude of the relation between current and future performance is useful to lenders, the precision of the prediction of next year's cash flows is also important. To empirically examine precision, I use the $\mathrm{R}^{2}$ from the models above. However, to calculate the $\mathrm{R}^{2} \mathrm{I}$ can no longer estimate the equation by maximum likelihood, so I instead use the two-step version of the endogenous switching model (see fn. 26). This requires first estimating equation (7) to derive the inverse Mills ratio $(I M R)$ which I then include in equation (11) to account for unobservable selection bias issues, resulting in the following equation:

$$
\begin{aligned}
\text { CFO }_{i, t+1}=\varphi_{0}+\varphi_{1} & \text { CFO }_{i, t}+\varphi_{2} \text { Accruals }_{i, t}+\varphi_{3} \text { IMR }_{i, t} \\
& +\sum_{j=4}^{11} \varphi_{j} \text { Industry }_{i, t}+\sum_{y=12}^{15} \varphi_{y} \text { Year }_{i, t}+v_{i, t}
\end{aligned}
$$

I estimate equation (12) by OLS for both audited and unaudited firms separately. ${ }^{38}$ The difference in the $\mathrm{R}^{2}$ for this regression across the two regimes is the statistic of interest.

\footnotetext{
${ }^{38}$ Various research has noted the sensitivity of the selection models to multicollinearity (e.g., Puhani 2000; Francis and Lennox 2008). This is not an issue in my study, as the variance inflation factors for all variables are less than 10 which has been suggested as a threshold value of potential multicollinearity concerns (Belsey, Kuh, and Welsch 1980).
} 
Table 4.4 reports the results. The $\mathrm{R}^{2}$ for the unaudited firms is $20.43 \%$, while the $\mathrm{R}^{2}$ for the audited firms is $28.72 \%$ - higher by $8.29 \%$. To test the statistical significance of the difference in the $\mathrm{R}^{2}$, I use a bootstrapping procedure (see Appendix $\mathrm{B}$ for a description) and find that the p-value of the difference in $\mathrm{R}^{2}$ is less than $1 \%$, providing statistical support for $\mathrm{H} 3$ that the financial statements of audited firms have higher predictive ability.

Because verification is likely to have the most significant impact on the precision of the accruals component of net income (as opposed to cash flows), I also measure the incremental impact of including accruals in equation (12). To do so, I reestimate equation (12) without Accruals $s_{i, t}$ and then calculate the incremental $\mathrm{R}^{2}$ improvement by including accruals for both unaudited and audited firms. I then compare the incremental improvement in $\mathrm{R}^{2}$ across unaudited and audited firms, producing a 'difference-in-difference' test isolating the precision of the accruals estimates for next year's cash flows. Table 4.4 reveals that accruals significantly improve the predictive ability for both unaudited and audited firms, but that the incremental improvement for firms with audits is significantly higher by $4.9 \%$. Again, I test the significance of this difference-in-difference by the bootstrapping technique and find a significance level of less than $1 \%$. To summarize, the financial statement information of audited firms produces more precise predictions of future cash flows compared to unaudited firms, and, in particular, the accruals are significantly more precise.

Finally, I explore the effect on accrual precision of the interaction between the external expertise of an auditor with the internal capabilities within the firm. If internal 
controls and accounting expertise improve as a firm increases in size, then I would expect accruals to map into future cash flows more strongly for larger firms without an audit. On the other hand, if the firm receives an audit (i.e., accounting expertise from outside the firm) then firm size should not be strongly related to accrual persistence for these firms. ${ }^{39}$ In Table 4.5 I re-estimate equation (11) by also interacting $\mathrm{CFO}_{i, t}$ and Accruals $_{i, t}$ with firm size $\left(L N(\text { Assets })_{i, t}\right)$ and find that, as in Table 4.3, Panel B, the primary coefficient on Accruals $s_{i, t}$ is significantly larger for audited firms, but that the interactive coefficient is significantly larger for unaudited firms, supporting the notion that the beneficial reporting effects are more pronounced in firms with weaker internal accounting mechanisms. ${ }^{40}$ Further, I find that the interest rate differential between unaudited and audited firms is also larger in smaller firms (see Table 4.2, Panel B), indicating that lenders recognize these incremental reporting benefits.

To summarize the accounting quality results, I find significant evidence that audited financial statements have higher predictive ability for future cash flows in support of H3. Specifically, I find that two characteristics that enhance predictive ability - persistence and precision - are higher for audited firms. Further, the persistence difference between audited and unaudited firms appears to be particularly

\footnotetext{
${ }^{39}$ In a recent exposure draft the American Institute of Certified Public Accountants (AICPA) notes: "Accountants have, and continue to play, an important role through the performance of services that help their clients, particularly smaller businesses, prepare quality financial statements. Because of the complexity of many accounting standards and because many small business entities do not have internal accounting expertise, an accountant's involvement in the preparation of the financial statements or the client's system of internal control over financial reporting improves the financial information and results in more informed decision making by financial statement users" (emphasis added) AICPA (2009).

${ }^{40}$ Rather than using interaction terms, I also examine this issue by using a piecewise linear approach with the sample median firm size as the partitioning point. Consistent with Table 4.5, I find that the difference in persistence is concentrated in the smaller firms and the difference in persistence in the larger firms is statistically insignificant.
} 
strong in the accruals component of income and in firms with weaker internal accounting mechanisms. 


\section{CHAPTER 5}

\section{Robustness Checks}

\subsection{Supplemental Tests}

I now examine the robustness of the results with a variety of supplemental tests. First, I reconsider the role of firm size. A significant difference between audited and unaudited firms is the distribution of firm size across the two regimes. In the main results I truncate the firm size at the largest unaudited firm to avoid a common support problem in which there are not comparable unaudited firms for all audited firms. I now make the firm size distribution more restrictive and require each firm to have at least one matching firm in the opposite regime with the same year and 2-digit NAICS code that is also within 25\% of the asset size (and no more than $\$ 2$ million in absolute difference). This reduces the sample size to 11,666 firm-years for the cost of debt analysis and 14,510 for the predictive ability analysis. After imposing these restrictions, inferences do not change, though I note is that the average treatment effect of an audit on the interest rate is somewhat reduced to 42 basis points (from 64 basis points).

Next, I reconsider the inclusion of firm-years with the lowest level of accounting service, a compilation. In the main tests, I consolidate compilation and review observations as "unaudited" observations; however, aside from a differing level of 
assurance, compilations differ from reviews and audits in two distinct ways: 1) the CPA conducting a compilation is not required to remain independent of the company; and, 2) footnotes are not a required to be included in compiled financial statements. To ensure that a lack of independence and differences in disclosure level are not materially impacting the analysis, I eliminate firm-years with compilations and only include reviews and audits. Despite the significant reduction in sample size, all findings remain economically similar and statistically significant, with the exception of the difference in the coefficients of Current Ratio in Table 4.2 which is not significant at standard levels.

As a third supplemental test, I reconsider the potential lack of independence across observations for a given firm over time. In the main tests, I cluster the standard errors at the firm level, however, an alternative methodology for addressing this issue is to utilize the "between estimator" in which all variables are averaged across time for each firm. This results in using only one observation per firm with all variation being derived from between firm differences. Again, all of the inferences on the variables of interest remain economically similar and statistically significant, with the exception of the difference in the coefficients of Interest Coverage in Table 4.2 which is not significant at standard levels.

\subsection{Propensity Score Matching}

The primary tests utilize an endogenous switching model which requires the identification of an instrumental variable. However, various studies note the difficulty in selecting a valid instrument which is truly exogenous (e.g., Francis and Lennox 2008; 
Larcker and Rusticus 2009). I now consider propensity score matching as an alternative to the endogenous switching model. Propensity score matching has the advantage that it explicitly matches firms to ensure comparability on observable factors. One potential concern of the propensity score matching approach is that, because firms are matched based only on observable characteristics, the propensity score match requires that observable factors account for all unobservable factors, such as management talent and banking relationships, which the endogenous switching model is able to account for as discussed in Chapter 4 (see Francis and Lennox 2008; Angrist and Pischke 2009; Armstrong, Jagolinzer, and Larcker 2009 for discussions of these issues). To implement this approach, I first create propensity scores for each firm based on the conditional probability of the firm being audited. This score is derived from a probit model similar to equation (7), but excludes the exogenous instrument. I then match each audited firm one-to-one with an unaudited firm with the closest propensity score, without replacement (i.e., each unaudited firm may only be matched once). Table 5.1 presents summary statistics of the two groups and it appears that the matching procedure works well as shown by the improved similarity across the samples. Using the matched samples, I repeat all analyses and inferences remain unchanged with the only exception of the analysis in Table 4.3, Panel B where the magnitude of the coefficients on $\mathrm{CFO}_{i, t}$ and Accruals $_{i, t}$ remain larger for audited firms; however, the difference is not statistically significant. All other inferences are unchanged, indicating that the results are empirically robust. 


\section{CHAPTER 6}

\section{Conclusion}

The verification of financial statements is a fundamental aspect of financial reporting. In this study I examine the role that financial statement verification plays in the debt financing process of privately-held firms. These firms create an ideal setting to investigate this issue because they do not face a mandated audit requirement, creating interesting variation in the extent to which third party auditors actually examine the financial statements. In addition, these firms neither publicly report their results nor have a publicly traded stock price, thus mitigating the effects of alternative verification mechanisms.

My findings are threefold. First, I find that firms with audited financial statements have a lower cost of debt by 64 basis points, on average, suggesting that lenders find the third party financial statement verification valuable. Second, I find that information from audited financial statements is used more intensively (i.e., is more highly associated with a firm's interest rate) in the debt pricing process. This finding is interesting because, while all firms in the sample generate financial information which is presumably verifiable, it indicates that the actual verification of the information is important to the financial statement users. Verification, thus, hardens 
the financial statement information. Finally, I suggest one mechanism through which this hardening occurs - audited financial statements are better predictors of future cash flows. The expertise (and independence) extended by third party accountants appears to be particularly fruitful in the accrual estimation process as I find evidence that accruals, in particular, are better predictors of future cash flow for audited firms. In sum, this evidence contributes to our understanding of how debt capital providers use financial information and how the verification of that information enhances its usefulness. 


\section{TABLE 3.1: Sample Selection}

Panel A presents the observation selection process. I received 122,275 firm-years from Sageworks, Inc. after I eliminate non-U.S., non-accrual basis firms and firm-years with missing data. I use these observations to calculate the State Audit variable (see Appendix A). I then eliminate firm-years which Sageworks' collected using an abbreviated input form which does not collect sufficient data to calculate all variables. I delete further observations because they have extreme values for at least one variable or have insufficient data to calculate the necessary variables. Panel B presents the distribution of the 26,005 firm-years by year.

Panel A: Firm-Year Selection

Initial U.S. accrual basis observations

Eliminate observations with abbreviated reports

Eliminate firms in Utilites, Finance and Insurance industries

Eliminate observations with extreme values

Eliminate observations with Total Assets $>\$ 259$ million

Subtotal firm-year observations

Eliminate firm-years without 2 consecutive years of data

Available accrual basis firm-year observations

Unique firms
Firm

Years

122,275

$(57,490)$

Panel B: Distribution of Firm-Years by Level of Assurance and Year

\begin{tabular}{|c|c|c|c|c|}
\hline \multirow[b]{2}{*}{ Year } & \multicolumn{4}{|c|}{ Number of Firm-Years } \\
\hline & Audit & Review & Compilation & Total \\
\hline 2001 & 23 & 42 & 56 & 121 \\
\hline 2002 & 153 & 242 & 293 & 688 \\
\hline 2003 & 434 & 865 & 885 & 2,184 \\
\hline 2004 & 944 & 1,938 & 1,787 & 4,669 \\
\hline 2005 & 1,618 & 2,977 & 2,328 & 6,923 \\
\hline 2006 & 1,840 & 3,441 & 2,130 & 7,411 \\
\hline 2007 & 972 & 2,187 & 850 & 4,009 \\
\hline Total & 5,984 & 11,692 & 8,329 & 26,005 \\
\hline
\end{tabular}




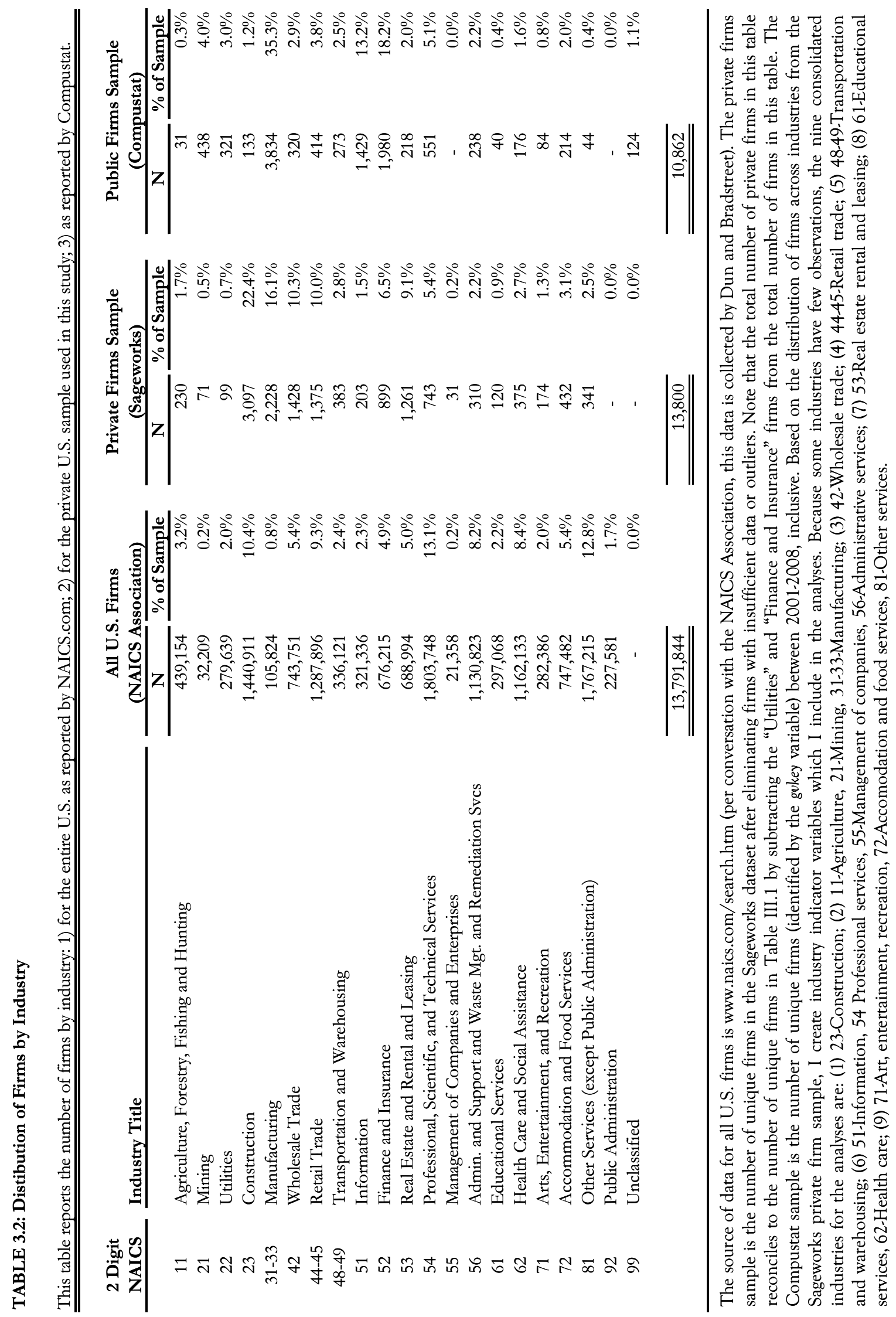




\section{TABLE 3.3: Descriptive Statistics}

This table presents summary statistics for all firm-years in the sample with sufficient data to be included in at least one of the regression analyses. Panel A reports the statistics for all firms. Panel B reports the statistics

Panel A: Unconditional

\begin{tabular}{|c|c|c|c|c|c|c|c|c|}
\hline Variable & Mean & Min & $25 \%$ & Med & $75 \%$ & $\operatorname{Max}$ & SD & $\mathbf{N}$ \\
\hline Audit & 0.23 & 0 & 0 & 0 & 0 & 1 & 0.42 & 26,005 \\
\hline Review & 0.45 & 0 & 0 & 0 & 1 & 1 & 0.50 & 26,005 \\
\hline Compilation & 0.32 & 0 & 0 & 0 & 1 & 1 & 0.47 & 26,005 \\
\hline Interest Rate & $7.3 \%$ & $1.5 \%$ & $5.4 \%$ & $7.0 \%$ & $8.8 \%$ & $18.0 \%$ & $3.0 \%$ & 17,684 \\
\hline Interest Coverage & 6.82 & -7.55 & 1.97 & 4.44 & 9.55 & 32.71 & 7.30 & 19,295 \\
\hline Current Ratio & 2.53 & 0.10 & 1.11 & 1.57 & 2.63 & 38.45 & 3.21 & 25,572 \\
\hline PPE & $32.3 \%$ & $0.0 \%$ & $8.7 \%$ & $22.8 \%$ & $50.5 \%$ & $100.0 \%$ & $28.3 \%$ & 26,005 \\
\hline Leverage & $67.3 \%$ & $0.0 \%$ & $44.2 \%$ & $66.2 \%$ & $85.7 \%$ & $199.9 \%$ & $34.1 \%$ & 26,005 \\
\hline Neg Equity & 0.13 & 0.00 & 0.00 & 0.00 & 0.00 & 1.00 & 0.34 & 26,005 \\
\hline Total Assets & 6.50 & 0.01 & 1.03 & 2.58 & 6.23 & 258.96 & 14.30 & 26,005 \\
\hline LN(Assets) & 1.43 & 0.01 & 0.71 & 1.27 & 1.98 & 5.56 & 0.93 & 26,005 \\
\hline Sales Growth & $8.1 \%$ & $-49.9 \%$ & $-4.1 \%$ & $5.1 \%$ & $17.5 \%$ & $100.0 \%$ & $22.3 \%$ & 26,005 \\
\hline C-Corp & 0.38 & 0.00 & 0.00 & 0.00 & 1.00 & 1.00 & 0.48 & 26,005 \\
\hline BRI & 1.69 & 0.00 & 0.00 & 1.00 & 3.00 & 4.00 & 1.45 & 26,005 \\
\hline State Audit & $18.4 \%$ & $8.1 \%$ & $13.3 \%$ & $17.9 \%$ & $20.3 \%$ & $38.5 \%$ & $6.8 \%$ & 26,005 \\
\hline NI & $7.4 \%$ & $-99.3 \%$ & $0.1 \%$ & $4.5 \%$ & $13.2 \%$ & $99.3 \%$ & $16.2 \%$ & 26,005 \\
\hline Accruals & -0.03 & -0.94 & -0.10 & -0.03 & 0.05 & 0.95 & 0.16 & 18,083 \\
\hline $\mathrm{CFO}$ & 0.11 & -0.93 & 0.01 & 0.08 & 0.20 & 1.00 & 0.19 & 18,083 \\
\hline
\end{tabular}

Panel B: Conditional on Attestation Level

\begin{tabular}{|c|c|c|c|c|c|c|c|c|}
\hline Variable & Mean & Min & $25 \%$ & Med & $75 \%$ & Max & SD & $\mathbf{N}$ \\
\hline \multicolumn{9}{|l|}{ Audit } \\
\hline Interest Rate & $6.8 \%$ & $1.5 \%$ & $4.9 \%$ & $6.7 \%$ & $8.3 \%$ & $17.9 \%$ & $2.9 \%$ & 4,253 \\
\hline Interest Coverage & 5.87 & -7.42 & 1.53 & 3.29 & 7.90 & 32.68 & 6.89 & 4,510 \\
\hline Current Ratio & 2.45 & 0.10 & 1.10 & 1.58 & 2.75 & 36.47 & 2.86 & 5,900 \\
\hline PPE & $40.9 \%$ & $0.0 \%$ & $10.6 \%$ & $32.0 \%$ & $74.0 \%$ & $99.5 \%$ & $32.8 \%$ & 5,984 \\
\hline Leverage & $72.4 \%$ & $0.1 \%$ & $47.1 \%$ & $69.3 \%$ & $90.3 \%$ & $199.5 \%$ & $37.4 \%$ & 5,984 \\
\hline Total Assets & 12.90 & 0.01 & 1.88 & 5.39 & 12.83 & 258.37 & 22.65 & 5,984 \\
\hline Sales Growth & $7.8 \%$ & $-49.5 \%$ & $-2.5 \%$ & $4.6 \%$ & $15.4 \%$ & $99.3 \%$ & $20.7 \%$ & 5,984 \\
\hline \multicolumn{9}{|l|}{ No Audit } \\
\hline Interest Rate & $7.5 \%$ & $1.5 \%$ & $5.5 \%$ & $7.1 \%$ & $9.0 \%$ & $18.0 \%$ & $3.0 \%$ & 13,431 \\
\hline Interest Coverage & 7.11 & -7.55 & 2.17 & 4.80 & 10.06 & 32.71 & 7.40 & 14,785 \\
\hline Current Ratio & 2.56 & 0.10 & 1.12 & 1.57 & 2.60 & 38.45 & 3.31 & 19,672 \\
\hline PPE & $29.7 \%$ & $0.0 \%$ & $8.3 \%$ & $21.0 \%$ & $45.5 \%$ & $100.0 \%$ & $26.2 \%$ & 20,021 \\
\hline Leverage & $65.8 \%$ & $0.0 \%$ & $43.4 \%$ & $65.4 \%$ & $84.3 \%$ & $199.9 \%$ & $32.9 \%$ & 20,021 \\
\hline Total Assets & 4.58 & 0.01 & 0.92 & 2.16 & 4.82 & 258.96 & 9.82 & 20,021 \\
\hline Sales Growth & $8.2 \%$ & $-49.9 \%$ & $-4.6 \%$ & $5.2 \%$ & $18.0 \%$ & $100.0 \%$ & $22.7 \%$ & 20,021 \\
\hline
\end{tabular}

See Appendix A for variable definitions. 


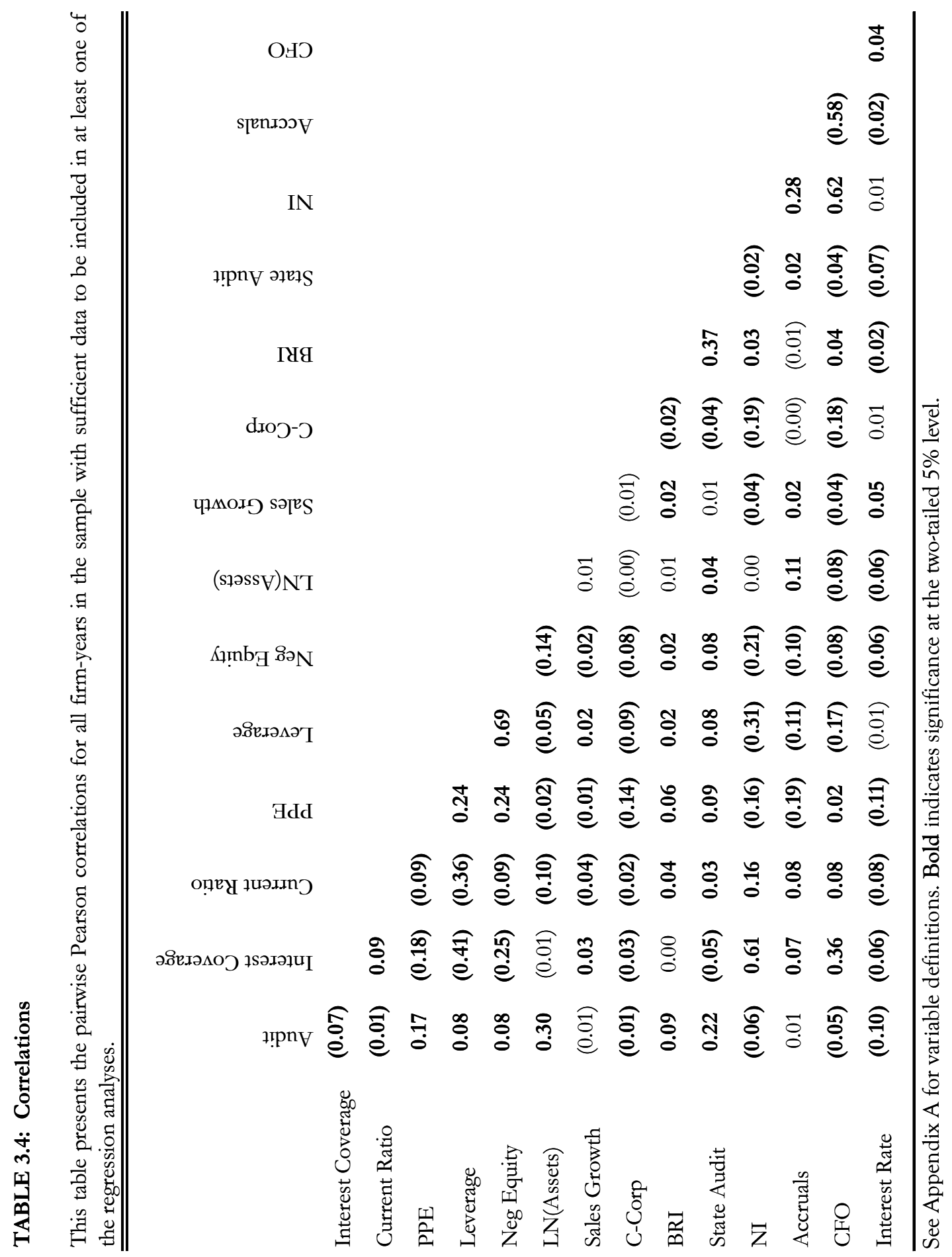




\section{TABLE 4.1: Probit Model of Audit Choice}

This table presents probit regression estimates of the probability of a firm receiving an audit. The dependent variable is 1 if the firm-year is audited and 0 otherwise.

\begin{tabular}{|c|c|}
\hline \multirow[b]{2}{*}{ Independent V ariables } & $\begin{array}{c}\text { Dependent Variable: } \\
\text { Audit }(=1 \text { or } 0)\end{array}$ \\
\hline & $\begin{array}{cc}\text { Coef. } & \text { Signif. } \\
z_{\text {-stat }} & \text { Level } \\
\end{array}$ \\
\hline State Audit & $\begin{array}{l}3.865 * * * \\
14.41\end{array}$ \\
\hline Interest Coverage & $\begin{array}{r}0.001 \\
0.52\end{array}$ \\
\hline Current Ratio & 0.008 \\
\hline PPE & $0.200 * *$ \\
\hline Leverage & -0.025 \\
\hline Neg Equity & $\begin{array}{c}0.235 \text { *** } \\
3.67\end{array}$ \\
\hline LN(Assets) & $\begin{array}{l}0.540 \text { *** } \\
25.93\end{array}$ \\
\hline Sales Growth & 0.010 \\
\hline C-Corp & $0.141 * * *$ \\
\hline BRI & -0.22 \\
\hline $\begin{array}{l}\text { Pseudo } \mathrm{R}^{2} \\
\text { Observations }\end{array}$ & $23.0 \%$ \\
\hline \multicolumn{2}{|c|}{$\begin{array}{l}\text { Industry and year fixed effects are included. See Appendix } \\
\text { A for variable definitions. Reported below the coefficients } \\
\text { are heteroskedasticity consistent } z \text {-statistics, clustered at the } \\
\text { firm level. }{ }^{*},{ }^{* *},{ }^{* * *} \text { indicate significance at the two-tailed } \\
10 \%, 5 \% \text { and } 1 \% \text { levels, respectively }\end{array}$} \\
\hline
\end{tabular}




\section{TABLE 4.2: Interest Rate Analysis}

This table presents the results from simultaneously estimating the audit choice and the average interest rate for both audited and unaudited firms. Panel A presents the regression coefficient estimates. Panel B presents predicted interest rates for all firms under both audited and unaudited regimes.

Panel A: Determinants of the Average Interest Rate

This panel presents the estimates from regressing the one-year ahead firm specific interest rate on current year firm financial and control variables. The reported estimates are derived from an endogenous switching model which simultaneously estimates the firm's choice to receive an audit and the firm's interest rate separately for firms that are unaudited and firms that are audited. The results for the audit choice model are very similar to the probit model results in Table 5 and are not presented here for brevity.

\begin{tabular}{|c|c|c|c|c|c|c|}
\hline & & Deper & variable: & Interest & $\mathrm{i}, \mathrm{t}+1$ & \\
\hline & (1) & & $(2$ & & (3) & \\
\hline & Unaud & ted & Aud & & Differc & nce \\
\hline Independent variables & $\begin{array}{l}\text { Coef. } \\
z_{\text {-stat }}\end{array}$ & $\begin{array}{r}\text { Signif. } \\
\text { Level }\end{array}$ & $\begin{array}{c}\text { Coef. } \\
z_{\text {-stat }}\end{array}$ & $\begin{array}{l}\text { Signif. } \\
\text { Level }\end{array}$ & $\begin{array}{c}(2)-(1) \\
z-\text {-stat }\end{array}$ & $\begin{array}{l}\text { Signif. } \\
\text { Level }\end{array}$ \\
\hline Interest Coverage & $\begin{array}{r}-0.05 \\
-11.0\end{array}$ & & $\begin{array}{r}-0.07 \\
-7 .\end{array}$ & & $\begin{array}{r}-0.022 \\
-2.01\end{array}$ & \\
\hline Current Ratio & $\begin{array}{r}-0.08 \\
-7.6\end{array}$ & $* * *$ & $\begin{array}{r}-0.13 \\
-5.8\end{array}$ & $* * *$ & $\begin{array}{r}-0.04 C \\
-1.96\end{array}$ & \#\# \\
\hline PPE & $\begin{array}{r}-0.62 \\
-4.1\end{array}$ & $* * *$ & $\begin{array}{r}-1.90 \\
-7 .\end{array}$ & $* * *$ & $\begin{array}{r}-1.368 \\
-4.52\end{array}$ & \#\#\# \\
\hline Leverage & $\begin{array}{r}-0.65 \\
-3.6\end{array}$ & *** & $\begin{array}{r}0.19 \\
0.6\end{array}$ & & $\begin{array}{r}0.851 \\
2.40\end{array}$ & \#\#\# \\
\hline Neg Equity & $\begin{array}{r}-0.04 \\
-0.3\end{array}$ & & $\begin{array}{r}-0.82 \\
-3 .\end{array}$ & $* * *$ & $\begin{array}{r}-0.78 \\
-2.8\end{array}$ & \#\#\# \\
\hline LN(Assets) & $\begin{array}{r}-0.23 \\
-4.4\end{array}$ & $* * *$ & $\begin{array}{r}-0.13 \\
-1 .\end{array}$ & & $\begin{array}{r}0.09 \\
0.9\end{array}$ & \\
\hline Sales Growth & $\begin{array}{r}0.25 \\
1.9\end{array}$ & $* *$ & $\begin{array}{r}1.05 \\
4 .\end{array}$ & $* * *$ & $\begin{array}{r}0.79 \\
2.9\end{array}$ & \#\#\# \\
\hline C-Corp & $\begin{array}{r}-0.15 \\
-2.1\end{array}$ & $* *$ & $\begin{array}{r}-0.10 \\
-1 .\end{array}$ & & $\begin{array}{r}-0.03 \\
-0.2\end{array}$ & \\
\hline BRI & $\begin{array}{r}0.02 \\
1.2\end{array}$ & & $\begin{array}{r}0.03 \\
0.5\end{array}$ & & $\begin{array}{r}0.005 \\
0.19\end{array}$ & \\
\hline Observations & 11,523 & & 3,75 & & & \\
\hline
\end{tabular}

Industry and year fixed effects are included. See Appendix A for variable definitions. Reported below the coefficients are heteroskedasticity consistent $z$-statistics, clustered at the firm level. ${ }^{*},{ }^{* *},{ }^{* * *}$ indicate significance at the two-tailed $10 \%, 5 \%$ and $1 \%$ levels, respectively. The differences in coefficient estimates (column 2 minus column 1) are presented in column (3). The differences are directional predictions and, therefore, \#, \#\#, \#\#\# indicate significance at the one-tailed 10\%, 5\% and 1\% levels, respectively.

\section{(Continued)}




\section{TABLE 4.2: Interest Rate Analysis (Continued)}

\section{Panel B: Predicted Interest Rates}

This panel presents the estimated interest rates for both audited and unaudited firms. To calculate the interest rate averages, I use the firm's actual interest rate under the regime that the firm actually reported (audited or unaudited) and I use the estimated coefficients from Panel A to calculate a fitted interest rate in the counterfactual regime (see equation (9)). Therefore, each interest rate figure is calculated using the full sample of firms from the regressions in Panel A. In addition to presenting the results for all firms, I also present the interest rates conditional on firm size, partitioned by the median size for audited firms.

\begin{tabular}{|c|c|c|c|}
\hline & $\begin{array}{l}\text { Predicted average interest } \\
\text { rate for both audited and } \\
\text { unaudited firms in the }\end{array}$ & $\begin{array}{l}\text { Predicted average interest } \\
\text { rate for both audited and } \\
\text { unaudited firms in the }\end{array}$ & \\
\hline & $\frac{1}{N} \sum_{i=1}^{N}\left(X_{i} \hat{\beta}_{1}\right)$ & $\frac{1}{N} \sum_{i=1}^{N} X_{i} \hat{\beta}_{0}$ & \\
\hline & $(1)$ & (2) & $(1)-(2)$ \\
\hline & Audit & No Audit & ATE \\
\hline \multicolumn{4}{|l|}{ Unconditional } \\
\hline All Firms & $7.05 \%$ & $7.69 \%$ & $-0.64 \% \$ \$ \$$ \\
\hline \multicolumn{4}{|c|}{ Conditional on Size (Partitioned at the median audited firm size: $\$ 5.4$ million in Total Assets) } \\
\hline Small & $7.09 \%$ & $7.80 \%$ & $-0.71 \% \$ \$ \$$ \\
\hline Large & $6.96 \%$ & $7.46 \%$ & $-0.50 \%$ \$\$ \\
\hline
\end{tabular}

Note that because the predicted interest rates are generated values, I use bootstrapping to test the statistical significance of the difference in interest rates across the audit/no audit regime (see Noreen 1989). To do so, I calculate p-values by: 1) randomly sampling observations from the sample (with replacement); 2) re-estimating the coefficients from Table IV.3; 3) calculating the ATE as per equation (9) to create a distribution of the ATE; and, 4) counting the number of observations of the bootstrapped sample which are non-negative to generate the p-value (i.e., the probability that the test statistic is non-negative). \$, \$\$, \$\$ indicate significance at the one-tailed $10 \%, 5 \%$ and $1 \%$ levels, respectively, based on the bootstrapped p-values. 


\section{TABLE 4.3: Cash Flow Prediction Model - Persistence Estimates}

This table present the results from regressing one-year ahead cash flow from operations on current net income (Panel A) and current cash flow from operations and current period accruals (Panel B). The reported estimates are derived from an endogenous switching model which simultaneously estimates the firm's choice to receive an audit and the firm's one-year ahead cash flows separately for firms that are unaudited and firms that are audited. The results for the audit choice model are very similar to the probit model results in Table 5 and are not presented here for brevity.

Panel A: Future Cash Flows as a Function of Net Income

\begin{tabular}{|c|c|c|c|c|c|c|}
\hline \multirow{4}{*}{ Independent variables } & \multicolumn{6}{|c|}{ Dependent variable: $\mathrm{CFO}_{\mathrm{i}, t+1}$} \\
\hline & \multicolumn{2}{|c|}{ (1) } & \multicolumn{2}{|c|}{ (2) } & \multicolumn{2}{|c|}{ (3) } \\
\hline & \multicolumn{2}{|c|}{ Unaudited } & \multicolumn{2}{|c|}{ Audited } & \multicolumn{2}{|c|}{ Difference } \\
\hline & $\begin{array}{l}\text { Coef } \\
z \text {-stat }\end{array}$ & Signif. & Coef. & $\begin{array}{l}\text { Signif. } \\
\text { Level }\end{array}$ & $\begin{array}{c}(2)-(1) \\
z \text {-stat }\end{array}$ & $\begin{array}{l}\text { Signif } \\
\text { Level }\end{array}$ \\
\hline $\mathrm{NI}_{\mathrm{i}, \mathrm{t}}$ & \multicolumn{2}{|c|}{$0.544 * * *$} & \multicolumn{2}{|c|}{$0.628 * * *$} & \multicolumn{2}{|c|}{$\begin{array}{c}0.084 \# \# \# \\
2.70\end{array}$} \\
\hline Observations & \multicolumn{2}{|c|}{13,764} & \multicolumn{2}{|c|}{4,041} & & \\
\hline
\end{tabular}

Panel B: Future Cash Flows as a Function of Cash Flows and Accruals

\begin{tabular}{|c|c|c|c|c|c|c|}
\hline \multirow[b]{4}{*}{ Independent variables } & \multicolumn{6}{|c|}{ Dependent variable: $\mathrm{CFO}_{\mathrm{i}, t+1}$} \\
\hline & \multicolumn{2}{|c|}{$(1)$} & \multirow{2}{*}{\multicolumn{2}{|c|}{$\frac{(2)}{\text { Audited }}$}} & \multirow{2}{*}{\multicolumn{2}{|c|}{$\frac{\text { (3) }}{\text { Difference }}$}} \\
\hline & \multicolumn{2}{|c|}{ Unaudited } & & & & \\
\hline & $\begin{array}{c}\text { Coef. } \\
z-\text { stat }\end{array}$ & $\begin{array}{r}\text { Signif. } \\
\text { Level } \\
\end{array}$ & $\begin{array}{c}\text { Coef. } \\
z \text {-stat }\end{array}$ & $\begin{array}{r}\text { Signif. } \\
\text { Level }\end{array}$ & $\begin{array}{c}(2)-(1) \\
z \text {-stat }\end{array}$ & $\begin{array}{l}\text { Signif. } \\
\text { Level }\end{array}$ \\
\hline $\mathrm{CFO}_{\mathrm{i}, \mathrm{t}}$ & \multicolumn{2}{|c|}{$\begin{array}{l}0.560 * * * \\
35.16\end{array}$} & \multicolumn{2}{|c|}{$\begin{array}{l}0.625 * * * \\
21.85\end{array}$} & \multicolumn{2}{|c|}{$\begin{array}{c}0.065 \# \# \\
2.01\end{array}$} \\
\hline Accruals $_{\mathrm{i}, \mathrm{t}}$ & $0.503 * * *$ & $* * *$ & \multicolumn{2}{|c|}{17.30} & \multicolumn{2}{|c|}{$\begin{array}{c}0.135 \text { \#\#\# } \\
3.32\end{array}$} \\
\hline Observations & 13,7 & & 4,0 & & \\
\hline
\end{tabular}

Industry and year fixed effects are included. See Appendix A for variable definitions. Reported below the coefficients are heteroskedasticity consistent z-statistics, clustered at the firm level. ${ }^{*}{ }^{* *},{ }^{* * *}$ indicate significance at the two-tailed $10 \%, 5 \%$ and $1 \%$ levels, respectively. The differences in coefficient estimates (column 2 minus column 1) are presented in column (3). The differences are directional predictions and, therefore, \#, \#\#, \#\#\# indicate significance at the one-tailed 10\%, 5\% and 1\% levels, respectively. 


\section{TABLE 4.4: Cash Flow Prediction Model - Precision Estimates}

This table reports the $\mathrm{R}^{2}$ from equation (12) for both unaudited and audited firms. I use the two-step endogenous switching model estimation approach in which I estimate the inverse Mills ratio (IMR) in the first step and include this estimate of the IMR in equation (12) in the second step. The second step is a regression with one-year ahead cash flows from operations as the dependent variable. The first row presents the $\mathrm{R}^{2}$ estimation results with $C F O_{i, t}$, Accruals ${ }_{i, t}$, and $I M \mathrm{R}_{i, t}$ as explanatory variables; while the second row presents the $\mathrm{R}^{2}$ estimation results with $C F O_{i, t}$ and $I M \mathrm{R}_{i, t}$ as the only explanatory variables. The coefficient estimates from this regression have been suppressed for brevity, but are similar to those in Table 7. I calculate the statistical signficance ( $\mathrm{p}$-value) of the difference in the $\mathrm{R}^{2}$ with a bootstrapping technique (see

\begin{tabular}{|c|c|c|c|c|}
\hline \multirow[b]{2}{*}{ Equation } & \multicolumn{4}{|c|}{$\mathrm{R}^{2}$} \\
\hline & Unaudited & Audited & Difference & p-value \\
\hline $\mathrm{CFO}_{\mathrm{i}, \mathrm{t}+1}=\mathrm{CFO}_{\mathrm{i}, \mathrm{t}}+$ Accruals $_{\mathrm{i}, \mathrm{t}}+\mathrm{IMR}_{\mathrm{i}, \mathrm{t}}+\mathrm{v}_{\mathrm{i}, \mathrm{t}}$ & $20.43 \%$ & $28.72 \%$ & $8.29 \%$ & $<0.01 * * *$ \\
\hline $\mathrm{CFO}_{\mathrm{i}, \mathrm{t}+1}=\mathrm{CFO}_{\mathrm{i}, \mathrm{t}}+\mathrm{IMR}_{\mathrm{i}, \mathrm{t}}+\mathrm{v}_{\mathrm{i}, \mathrm{t}}$ & $10.86 \%$ & $14.25 \%$ & $3.39 \%$ & $0.03 * *$ \\
\hline Difference & $9.57 \%$ & $14.47 \%$ & $4.90 \%$ & $<0.01 * * *$ \\
\hline
\end{tabular}

Industry and year fixed effects are included. See Appendix A for variable definitions. ${ }^{*},{ }^{* *},{ }^{* *}$ indicate significance at the two-tailed $10 \%, 5 \%$ and $1 \%$ levels, respectively. 


\section{TABLE 4.5: Cash Flow Prediction Model with Firm Size Interaction Terms}

This table presents the results from regressing one-year ahead cash flows from operations on current cash flows from operations and current period accruals interacted with $L N$ (Assets). The reported estimates are derived from an endogenous switching model which simultaneously estimates the firm's choice to receive an audit and the firm's one-year ahead cash flows separately for firms that are unaudited and firms that are audited. The results for the audit choice model are very similar to the probit model results in Table 5 and are suppressed for brevity.

\begin{tabular}{|c|c|c|c|c|c|c|}
\hline \multirow[b]{4}{*}{ Independent variables } & \multicolumn{6}{|c|}{ Dependent variable: $\mathrm{CFO}_{\mathrm{i}, \mathrm{t}+1}$} \\
\hline & \multicolumn{2}{|c|}{$(1)$} & \multicolumn{2}{|c|}{$(2)$} & \multicolumn{2}{|c|}{ (3) } \\
\hline & \multicolumn{2}{|c|}{ Unaudited } & \multicolumn{2}{|c|}{ Audited } & \multicolumn{2}{|c|}{ Difference } \\
\hline & $\begin{array}{l}\text { Coef. } \\
z^{-s t a t}\end{array}$ & $\begin{array}{c}\text { Signif. } \\
\text { Level }\end{array}$ & $\begin{array}{c}\text { Coef. } \\
z_{\text {-stat }}\end{array}$ & $\begin{array}{r}\text { Signif. } \\
\text { Level } \\
\end{array}$ & $\begin{array}{c}(2)-(1) \\
z^{-s t a t}\end{array}$ & $\begin{array}{r}\text { Signif. } \\
\text { Level } \\
\end{array}$ \\
\hline \multirow[t]{2}{*}{$\mathrm{CFO}_{\mathrm{i}, \mathrm{t}}$} & \multicolumn{2}{|c|}{$0.430 * * *$} & \multicolumn{2}{|c|}{$0.528 * * *$} & \multicolumn{2}{|c|}{$0.098 \#$} \\
\hline & \multicolumn{2}{|c|}{15.71} & \multicolumn{2}{|c|}{8.25} & \multicolumn{2}{|c|}{1.42} \\
\hline \multirow[t]{2}{*}{$\mathrm{CFO}_{\mathrm{i}, \mathrm{t}} * \mathrm{LN}(\text { Assets })_{\mathrm{i}, \mathrm{t}}$} & \multicolumn{2}{|c|}{$0.134 * * *$} & \multicolumn{2}{|c|}{$0.057 * *$} & \multicolumn{2}{|c|}{$-0.077 \# \# \#$} \\
\hline & \multicolumn{2}{|c|}{7.52} & \multicolumn{2}{|c|}{2.03} & \multicolumn{2}{|c|}{-2.30} \\
\hline \multirow[t]{2}{*}{ Accruals $_{i, t}$} & \multicolumn{2}{|c|}{$0.308 * * *$} & \multicolumn{2}{|c|}{$0.550 * * *$} & \multicolumn{2}{|c|}{$0.242 \# \# \#$} \\
\hline & \multicolumn{2}{|c|}{10.01} & \multicolumn{2}{|c|}{6.89} & \multicolumn{2}{|c|}{2.84} \\
\hline \multirow[t]{2}{*}{ Accruals $_{\mathrm{i}, \mathrm{t}} * \mathrm{LN}(\text { Assets })_{\mathrm{i}, \mathrm{t}}$} & \multicolumn{2}{|c|}{$0.199 * * *$} & \multicolumn{2}{|c|}{0.053} & \multicolumn{2}{|c|}{$-0.146 \# \# \#$} \\
\hline & \multicolumn{2}{|c|}{8.74} & \multicolumn{2}{|c|}{1.48} & \multicolumn{2}{|c|}{-3.42} \\
\hline \multirow[t]{2}{*}{$\mathrm{LN}(\text { Assets })_{\mathrm{i}, \mathrm{t}}$} & \multicolumn{2}{|c|}{0.000} & 0.00 & & 0.00 & \\
\hline & -0.06 & & 0.5 & & 0.5 & \\
\hline Observations & 13,764 & & 4,04 & & & \\
\hline $\begin{array}{l}\text { Industry and year fixed } \\
\text { Reported below the coef } \\
\text { the firm level. *, }{ }^{* *},{ }^{* * *} \\
\text { respectively. The differe } \\
\text { presented in column (3) } \\
\text { \#\#,\#\#\# indicate significa }\end{array}$ & $\begin{array}{l}\text { cts are in } \\
\text { nts are } h \\
\text { cate sign } \\
\text { in coeff } \\
\text { e differe }\end{array}$ & $\begin{array}{l}\text { cluded. } \\
\text { eteroske } \\
\text { ificance } \\
\text { icient e }\end{array}$ & $\begin{array}{l}\text { Appen } \\
\text { ticity cor } \\
\text { he two-ts } \\
\text { ates (col } \\
\text { ectional }\end{array}$ & $\begin{array}{l}\text { ix A for } \\
\text { istent } t- \\
\text { led } 10 \% \\
\text { imn } 2 \\
\text { oredictic }\end{array}$ & $\begin{array}{l}\text { riable def } \\
\text { tistics, clus } \\
5 \% \text { and } 19 \\
\text { tus colum } \\
\text { and, ther }\end{array}$ & $\begin{array}{l}\text { nitions. } \\
\text { tered at } \\
6 \text { levels, } \\
\text { 1) are } \\
\text { fore, \#, } \\
\text { ly. }\end{array}$ \\
\hline
\end{tabular}




\section{TABLE 5.1: Propensity Score Matched Sample Descriptive Statistics}

This table presents summary statistics for the propensity score matched samples. Panel A presents the summary statistics for the cost of debt analysis matched pairs; Panel B presents the summary statistics for the

Panel A: Cost of Debt Matched Pairs Summary Statistics

\begin{tabular}{|c|c|c|c|c|c|c|c|c|}
\hline Variable & Mean & Min & $25 \%$ & Med & $75 \%$ & $\operatorname{Max}$ & SD & $\mathbf{N}$ \\
\hline \multicolumn{9}{|l|}{ Audit } \\
\hline Interest Rate & $6.8 \%$ & $1.5 \%$ & $5.1 \%$ & $6.7 \%$ & $8.3 \%$ & $17.9 \%$ & $2.9 \%$ & 3,757 \\
\hline Interest Coverage & 5.34 & -7.40 & 1.48 & 2.97 & 7.00 & 32.68 & 6.38 & 3,757 \\
\hline Current Ratio & 2.26 & 0.10 & 1.04 & 1.49 & 2.50 & 36.47 & 2.52 & 3,757 \\
\hline PPE & $49.6 \%$ & $0.0 \%$ & $18.6 \%$ & $48.1 \%$ & $83.8 \%$ & $99.5 \%$ & $32.7 \%$ & 3,757 \\
\hline Leverage & $83.1 \%$ & $8.1 \%$ & $59.4 \%$ & $77.9 \%$ & $98.5 \%$ & $199.5 \%$ & $35.2 \%$ & 3,757 \\
\hline LN(Assets) & 1.98 & 0.01 & 0.99 & 1.91 & 2.72 & 5.56 & 1.15 & 3,757 \\
\hline Sales Growth & $7.4 \%$ & $-47.2 \%$ & $-1.9 \%$ & $4.2 \%$ & $13.9 \%$ & $99.3 \%$ & $19.3 \%$ & 3,757 \\
\hline \multicolumn{9}{|l|}{ No Audit } \\
\hline Interest Rate & $7.2 \%$ & $1.5 \%$ & $5.6 \%$ & $6.9 \%$ & $8.4 \%$ & $18.0 \%$ & $2.7 \%$ & 3,757 \\
\hline Interest Coverage & 6.18 & -7.55 & 1.90 & 3.86 & 8.33 & 32.65 & 6.68 & 3,757 \\
\hline Current Ratio & 2.14 & 0.10 & 0.96 & 1.35 & 2.11 & 36.66 & 3.13 & 3,757 \\
\hline PPE & $44.0 \%$ & $0.0 \%$ & $14.7 \%$ & $40.5 \%$ & $71.8 \%$ & $99.9 \%$ & $31.0 \%$ & 3,757 \\
\hline Leverage & $78.1 \%$ & $5.1 \%$ & $59.0 \%$ & $75.5 \%$ & $92.4 \%$ & $199.9 \%$ & $30.5 \%$ & 3,757 \\
\hline LN(Assets) & 1.99 & 0.02 & 1.35 & 2.02 & 2.55 & 5.56 & 0.92 & 3,757 \\
\hline Sales Growth & $7.9 \%$ & $-49.3 \%$ & $-2.4 \%$ & $5.2 \%$ & $15.6 \%$ & $100.0 \%$ & $20.3 \%$ & 3,757 \\
\hline
\end{tabular}

$\underline{\text { Panel B: Cash Flow Predictive Ability Matched Pairs Summary Statistics }}$

\begin{tabular}{|c|c|c|c|c|c|c|c|c|}
\hline Variable & Mean & Min & $25 \%$ & Med & $75 \%$ & $\operatorname{Max}$ & SD & $\mathbf{N}$ \\
\hline \multicolumn{9}{|l|}{ Audit } \\
\hline NI & $6.7 \%$ & $-93.1 \%$ & $-0.8 \%$ & $3.9 \%$ & $11.8 \%$ & $91.1 \%$ & $15.4 \%$ & 4,041 \\
\hline Current Ratio & 2.53 & 0.10 & 1.14 & 1.63 & 2.87 & 36.06 & 2.91 & 4,041 \\
\hline PPE & $37.3 \%$ & $0.0 \%$ & $8.6 \%$ & $26.6 \%$ & $65.0 \%$ & $99.1 \%$ & $32.0 \%$ & 4,041 \\
\hline Leverage & $68.8 \%$ & $0.7 \%$ & $42.6 \%$ & $65.1 \%$ & $87.6 \%$ & $199.5 \%$ & $37.7 \%$ & 4,041 \\
\hline LN(Assets) & 1.93 & 0.01 & 1.06 & 1.84 & 2.60 & 5.56 & 1.10 & 4,041 \\
\hline Sales Growth & $7.1 \%$ & $-49.5 \%$ & $-3.1 \%$ & $4.2 \%$ & $14.9 \%$ & $99.3 \%$ & $20.5 \%$ & 4,041 \\
\hline \multicolumn{9}{|l|}{ No Audit } \\
\hline NI & $7.5 \%$ & $-77.0 \%$ & $0.7 \%$ & $4.7 \%$ & $12.2 \%$ & $95.0 \%$ & $14.4 \%$ & 4,041 \\
\hline Current Ratio & 2.53 & 0.10 & 1.07 & 1.49 & 2.55 & 38.13 & 3.42 & 4,041 \\
\hline PPE & $33.5 \%$ & $0.0 \%$ & $8.2 \%$ & $23.0 \%$ & $55.3 \%$ & $99.9 \%$ & $29.6 \%$ & 4,041 \\
\hline Leverage & $65.3 \%$ & $0.1 \%$ & $42.0 \%$ & $65.6 \%$ & $84.7 \%$ & $199.9 \%$ & $33.7 \%$ & 4,041 \\
\hline LN(Assets) & 1.91 & 0.02 & 1.27 & 1.92 & 2.50 & 5.36 & 0.92 & 4,041 \\
\hline Sales Growth & $7.9 \%$ & $-49.4 \%$ & $-3.6 \%$ & $5.3 \%$ & $16.6 \%$ & $99.4 \%$ & $21.0 \%$ & 4,041 \\
\hline
\end{tabular}




\section{APPENDIX A}

\section{Variable Definitions}

\begin{tabular}{|c|c|}
\hline Variable & Description \\
\hline Audit & $\begin{array}{l}\text { An indicator variable equal to } 1 \text { if the firm received a financial } \\
\text { statement audit; } 0 \text { otherwise. }\end{array}$ \\
\hline Review & $\begin{array}{l}\text { An indicator variable equal to } 1 \text { if the firm received a financial } \\
\text { statement review; } 0 \text { otherwise. }\end{array}$ \\
\hline Compilation & $\begin{array}{l}\text { An indicator variable equal to } 1 \text { if the firm received a financial } \\
\text { statement compilation; } 0 \text { otherwise. }\end{array}$ \\
\hline Interest Rate & 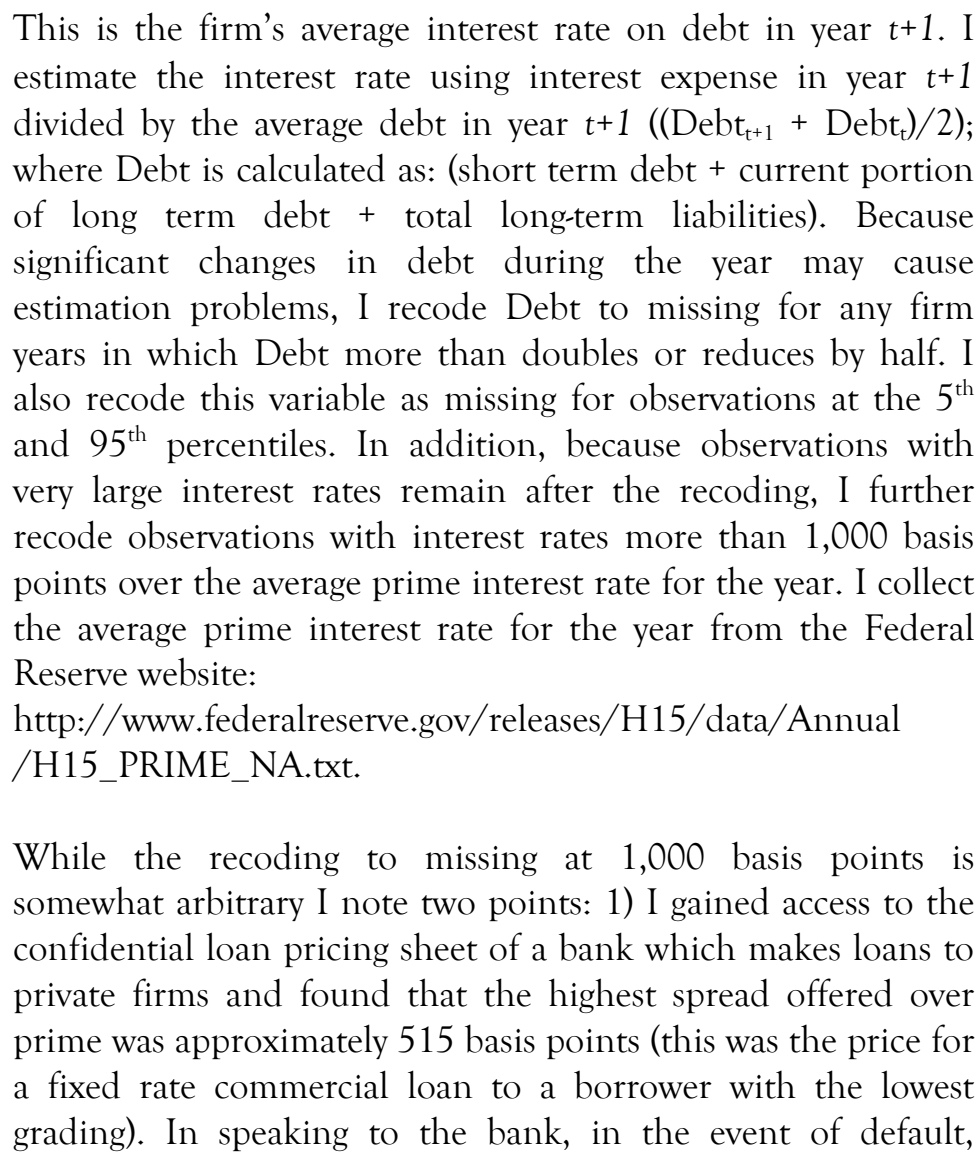 \\
\hline
\end{tabular}




\begin{tabular}{|c|c|}
\hline & $\begin{array}{l}\text { interest rates may escalate beyond this spread, but the initial } \\
\text { pricing offer usually does not. The bank noted that they simply } \\
\text { would not extend a potential borrower a loan rather than } \\
\text { increasing the spread, consistent with the theoretical notions of } \\
\text { Stiglitz and Weiss ( } 1981 \text { ); and, 2) In sensitivity tests, I use } \\
\text { truncation points of } 600 \text { basis points and } 1,200 \text { basis points } \\
\text { and find very similar results. }\end{array}$ \\
\hline Interest Coverage & $\begin{array}{l}\text { Earnings before Interest, Taxes, Depreciation and Amortization } \\
\text { expenses divided by Interest expense. To mitigate the effect of } \\
\text { outliers, I recode this variable as missing for observations } \\
\text { beyond the } 1^{\text {st }} \text { and } 99^{\text {th }} \text { percentiles. In addition, because firms } \\
\text { with very minimal interest expense create significant right-tailed } \\
\text { skewness, I only consider firms with interest expense which is at } \\
\text { least } 1 \% \text { of sales in determining the percentile cutoffs (I also } \\
\text { use } 0.5 \% \text { of sales with similar results). As a check on the } \\
\text { distribution of this variable, I note that the maximum of } 33 \text { is } \\
\text { very similar to the median of firms rated AAA by Standard \& } \\
\text { Poors (Note that there are } 6 \text { firms in the AAA category, so the } \\
\text { median is also similar to the maximum of this distribution). See } \\
\text { Lugg (2008). }\end{array}$ \\
\hline Current Ratio & $\begin{array}{l}\text { Year-end total current assets divided by year-end total current } \\
\text { liabilities. To mitigate the effect of outliers, I recode } \\
\text { observations beyond the } 1^{\text {st }} \text { and } 99^{\text {th }} \text { percentiles as missing. }\end{array}$ \\
\hline PPE & $\begin{array}{l}\text { Year-end net value of property, plant, and equipment divided } \\
\text { by year-end total assets. I eliminate firm-years in which the net } \\
\text { value of the property, plant, and equipment exceeds the total } \\
\text { assets. }\end{array}$ \\
\hline Leverage & $\begin{array}{l}\text { Year-end total liabilities divided by year-end total assets. To } \\
\text { mitigate the influence of firms with significant negative equity } \\
\text { positions, I eliminate firm-years in which total liabilities are } \\
\text { more than twice the magnitude of total assets. }\end{array}$ \\
\hline Neg Equity & $\begin{array}{l}\text { An indicator variable equal to } 1 \text { if total year-end liabilities are } \\
\text { greater than total year-end assets; } 0 \text { otherwise. }\end{array}$ \\
\hline Total Assets & Total assets ( $\$$ millions) at year-end. \\
\hline LN(Assets) & The natural log of (1+Total Assets). \\
\hline Sales Growth & $\begin{array}{l}\text { Year-over-year percentage change in sales in year } t+1 \text {. To avoid } \\
\text { losing a substantial number of observations by requiring three } \\
\text { consecutive years of data }(t-1, t \text {, and } t+1) \text { for the cost of debt } \\
\text { analysis, I calculate Sales Growth in year } t+1 \text { (i.e., the same year } \\
\text { as the interest rate calculation). Therefore, Sales Growth is } \\
\left.\text { calculated: (Sales }{ }_{t+1}-\text { Sales }_{t}\right) / \text { Sales }_{\mathrm{t}} \text {. To ensure that this choice is } \\
\text { not influencing the analysis, I re-examine the results excluding } \\
\text { Sales Growth and inferences are unchanged. }\end{array}$ \\
\hline
\end{tabular}




\begin{tabular}{|c|c|}
\hline C-Corp & $\begin{array}{l}\text { An indicator variable equal to } 1 \text { if the firm is incorporated } \\
\text { under subchapter } C \text { of the internal revenue code; } 0 \text { otherwise. }\end{array}$ \\
\hline BRI & $\begin{array}{l}\text { The Branching Restriction Index is the number of restrictions } \\
\text { on interstate branching in a particular state from Rice and } \\
\text { Strahan (2008), Table } 1 \text {. Zero indicates a state that is most open } \\
\text { to out-of-state entry, while a value of } 4 \text { is the most restrictive. } \\
\text { From Rice and Strahan (2008) pg. } 11 \text {, the four restrictions that } \\
\text { they examine are: } 1 \text { ) if a state imposes a minimum age on target } \\
\text { institutions of interstate acquirers of } 3 \text { or more years; } 2 \text { ) if a } \\
\text { state does not permit de novo interstate branching; } 3 \text { ) if a state } \\
\text { does not permit the acquisition of individual branches by an } \\
\text { out-of-state bank; and } 4 \text { ) if a state imposes a deposit cap less } \\
\text { than } 30 \% \text {. }\end{array}$ \\
\hline State Audit & $\begin{array}{l}\text { The value of this variable is calculated for each U.S. state as the } \\
\text { number of firm-years within the state that receive audits divided } \\
\text { by the total number of firm-years within that state, creating a } \\
\text { state specific audit percentage. I calculate the value of this } \\
\text { variable prior to eliminating observations with insufficient } \\
\text { financial data to include in the analysis. }\end{array}$ \\
\hline NI & Net income divided by year-end total assets. \\
\hline Accruals & $\begin{array}{l}\text { Because cash flow statement data is not available, I follow Sloan } \\
\text { (1996) and use the balance sheet approach to calculate accruals } \\
\text { (all changes are year-end balances from years } t-1 \text { to } t \text { ): Accruals }= \\
\Delta \text { Current Assets }-\Delta \text { Current Liabilities }-\Delta \text { Cash }+\Delta \text { Current } \\
\text { Portion of Long Term Debt }+\Delta \text { Short Term Debt - } \\
\text { Depreciation - Amortization. This value is then divided by } \\
\text { assets at the end of year } t \text {. }\end{array}$ \\
\hline $\mathrm{CFO}$ & $\begin{array}{l}\text { Cash flow from operations calculated as Net Income } e_{t}- \\
\text { Accruals }_{\mathrm{t}} \text { (before accruals are scaled by year-end assets). This } \\
\text { difference is divided by total assets at the end of year } t \text {. }\end{array}$ \\
\hline
\end{tabular}




\section{APPENDIX B}

\section{Bootstrap Test}

To test the statistical significance of the difference in $\mathrm{R}^{2}$ values, I use a bootstrap procedure which uses the sample data to generate a distribution for the test statistic (see Noreen 1989 who refers to this process as 'approximate randomization'). The advantage of this approach over standard parametric inference is that it does not require the empiricist to make any parametric assumptions regarding the distribution of the test statistic. Specifically in the case of comparing the $\mathrm{R}^{2}$ from both unaudited and audited firms, my test statistic is the difference between the $\mathrm{R}^{2}$ of the two cash flow prediction regressions (see Dichev and Tang 2009 for a very similar use of this bootstrapping approach to testing the difference in $\mathrm{R}^{2}$ values).

My hypothesis is that the difference in $\mathrm{R}^{2}$ is driven by the audited firms having

more precise (i.e., less noisy) information, thus increasing the $\mathrm{R}^{2}$. Thus the null hypothesis is that there is no difference in the $\mathrm{R}^{2}$ in audited and unaudited firms and I use the bootstrapping technique to test this by examining how frequently the actual observed difference in $\mathrm{R}^{2}$ would occur randomly. To do so, this approach involves three steps: 1) I randomly shuffle the audit indicator variable across all firms (i.e., randomly assign firms to be in the audited/unaudited pools); 2) I then re-estimate equation (11) for both 'pseudo-audited' and 'pseudo-unaudited' firms and record the 
difference in $R^{2}$ values from these regressions; and 3) I note if the difference in $R^{2}$ from the randomly generated samples is larger than the actual difference in $\mathrm{R}^{2}$ of $8.29 \%$. I repeat the steps 10,000 times and the resulting p-value is the number of times that the randomly generated difference in $\mathrm{R}^{2}$ is larger than the actual difference in $\mathrm{R}^{2}$ divided by the number of iterations. Note that this approach is also referred to as an "approximate randomization" test because the procedure randomizes across audited and unaudited firms (Noreen 1989). 


\section{BIBLIOGRAPHY}

American Institute of Certified Public Accountants (AICPA). 2009. Exposure Draft: Proposed Statements on Standards for Accounting and Review Services. New York, NY: AICPA.

Allee, K., and T. Yohn. 2009. The Demand for Financial Statements in an Unregulated Environment: An Examination of the Production and Use of

Financial Statements by Privately-held Small Businesses. The Accounting Review 84(1): $1-25$.

Almazan, A., S. Banerji, and A. DeMotta. 2008. Attracting Attention: Cheap Managerial Talk and Costly Market Monitoring. The Journal of Finance 63(3): 1399-1436.

Angrist, J., and J.-S. Pischke. 2009. Mostly Harmless Econometrics. Princeton, NJ: Princeton University Press.

Arens, A., R. Elder, and M. Beasley. 2005. Auditing and Assurance Services: An Integrated Approach. 10th ed. Upper Saddle River, NJ: Pearson Education, Inc.

Armstrong, C., W. Guay, and J. Weber. 2010. The Role of Information and Financial Reporting in Corporate Governance and Debt Contracting. Working paper. 
Armstrong, C., A. Jagolinzer, and D. Larcker. 2009. Chief Executive Officer Equity Incentives and Accounting Irregularities. Journal of Accounting Research 48(2): 225 271.

Ball, R. 2001. Infrastructure Requirements for an Economically Efficient System of Public Financial Reporting and Disclosure. Brookings-Wharton Papers on Financial Services: 127-169

Ball, R., S. Jayaraman, and L. Shivakumar. 2009. The Complementary Roles of Audited Financial Reporting and Voluntary Disclosure: A Test of the Confirmation Hypothesis. Working paper.

Ball, R., and L. Shivakumar. 2005. Earnings quality in UK private firms: comparative loss recognition timeliness. Journal of Accounting $\mathcal{E}$ Economics 39(1): 83-128.

Barth, M. E., D. P. Cram, and K. K. Nelson. 2001. Accruals and the prediction of future cash flows. The Accounting Review 76(1): 27-58.

Beatty, R. P. 1989. Auditor Reputation and the Pricing of Initial Public Offerings. The Accounting Review 64 (4): 693-709.

Becker, C., M. DeFond, J. Jiambalvo, and K. R. Subramanyam. 1998. The effect of audit quality on earnings management. Contemporary Accounting Research 15(1): 124.

Belsey, D., E. Kuh, and E. Welsch. 1980. Regression diagnostics: Identifying influential data and sources of collinearity. New York, NY: Wiley and Sons. 
Berger, A. N., and G. F. Udell. 1995. Relationship Lending and Lines of Credit in Small Firm Finance. The Journal of Business 68 (3):351-381.

—. 1998. The economics of small business finance: The roles of private equity and debt markets in the financial growth cycle. Journal of Banking $\mathcal{G}$ Finance 22: 613. 673.

—. 2006. A more complete conceptual framework for SME finance. Journal of Banking $\mathcal{E}$ Finance 30(11): 2945-2966.

Bharath, S. T., J. Sunder, and S. V. Sunder. 2008. Accounting Quality and Debt Contracting. The Accounting Review 83(1): 1-28.

Blackwell, D., T. Noland, and D. Winters. 1998. The value of auditor assurance: Evidence from loan pricing. Journal of Accounting Research 36(1): 57-70.

Burgstahler, D., L. Hail, and C. Leuz. 2006. The Importance of Reporting Incentives: Earnings Management in European Private and Public Firms. The Accounting Review 81(5): 983-1016.

Chow, C. 1982. The Demand for External Auditing: Size, Debt and Ownership Influences. The Accounting Review 57(2): 272-291.

Clor-Proell, S. 2009. The Effects of Expected and Actual Accounting Choices on Judgments and Decisions. The Accounting Review 84(5): 1465-1493.

Datar, S. M., G. A. Feltham, and J. S. Hughes. 1991. The role of audits and audit quality in valuing new issues. Journal of Accounting and Economics 14(1): 3-49. 
DeAngelo, L. E. 1981. Auditor size and audit quality. Journal of Accounting and Economics 3(3): 183-199.

Dichev, I. and V. Tang. 2009. Earnings Volatility and Earning Predictability. Journal of Accounting and Economics 47: 160-181.

Dixon, L., S. Gates, K. Kapur, S. Seabury, and E. Talley. 2006. The Impact of Regulation and Litigation on Small Business and Entrepreneurship: KauffmanRAND Center for the Study of Small Business and Regulation.

Dyck, A., and L. Zingales. 2004. Private Benefits of Control: An International Comparison. The Journal of Finance 59(2): 537-600.

Financial Accounting Standards Board (FASB). 1978. Objectives of Financial Reporting by Business Enterprises. Stamford, CT: FASB.

—. 1980. Qualitative Characteristics of Accounting Information. Stamford, CT: FASB.

Fortin, S., and J. A. Pittman. 2007. The role of auditor choice in debt pricing in private firms. Contemporary Accounting Research 24(3): 859-896.

Francis, J., R. LaFond, P. Olsson, and K. Schipper. 2004. Costs of Equity and Earnings Attributes. The Accounting Review 79(4): 967-1010.

—. 2005. The market pricing of accruals quality. Journal of Accounting and Economics 39(2): 295-327. 
Francis, J., and C. Lennox. 2008. Selection Models in Accounting Research. Working paper.

Francis, J., E. Maydew, and C. Sparks. 1999. The role of Big 6 auditors in the credible reporting of accruals. Auditing 18(2): 17-34.

Frankel, R. M., M. F. Johnson, and K. K. Nelson. 2002. The Relation between Auditors' Fees for Nonaudit Services and Earnings Management. The Accounting Review 77: 71-105.

Ghicas, D., A. Papadaki, G. Siougle, T. Sougiannis. 2007. The Relevance of Quantifiable Audit Qualifications in the Valuation of IPOs. Review of Accounting Studies 13: 512-550.

Grossman, S. J., and J. E. Stiglitz. 1976. Information and Competitive Price Systems. The American Economic Review 66(2): 246-253.

Holmstrom, B., and J. Roberts. 1998. The Boundaries of the Firm Revisited. The Journal of Economic Perspectives 12(4): 73-94.

Holmstrom, B., and J. Tirole. 1993. Market Liquidity and Performance Monitoring. The Journal of Political Economy 101 (4): 678-709.

Hope, O., W. Thomas, and D. Vyas. 2010. Transparency, Ownership, and Financing Constraints: An International Study Using Private Firms. Working paper.

Ijiri, Y. 1975. Theory of Accounting Measurement. Sarasota, FL: American Accounting Association. 
Jensen, M. C., and W. H. Meckling. 1976. Theory of the firm: Managerial behavior, agency costs and ownership structure. Journal of Financial Economics 3(4): 305-360.

Johnstone, K. 2000. Client-acceptance Decisions: Simultaneous Effects of Client Business Risk, Audit Risk, Auditor Business Risk, and Risk Adaptation. Auditing 19(1): $1-25$.

Kim, J.-B., D. Simunic, M. Stein, and C. Yi. 2007. Voluntary Audits and the Cost of Debt Capital for Privately-held Firms: Korean Evidence. Working paper.

Kothari, S. P., K. Ramanna, and D. Skinner. 2010. Implications for GAAP from an Analysis of Positive Research in Accounting. Working paper.

Larcker, D., and S. Richardson. 2004. Fees Paid to Audit Firms, Accrual Choices, and Corporate Governance. Journal of Accounting Research 42(3): 625-658.

Libby, R. 1979. The Impact of Uncertainty Reporting on the Loan Decision. Journal of Accounting Research 17: 35-57.

Lugg, D. 2008. 2007 Adjusted Key U.S. Industrial and Utility Financial Ratios: Standard \& Poors.

Maddala, G. S. 1983. Limited-dependent and Qualitative Variables in Econometrics. Melbourne, Australia: Cambridge University Press.

—. 1991. A Perspective on the Use of Limited-Dependent and Qualitative Variables Models in Accounting Research. The Accounting Review 66 (4):788-807. 
Maines, L., and J. Wahlen. 2006. The Nature of Accounting Information Reliability: Inferences from Archival and Experimental Research. Accounting Horizons 20 (4): $399-425$.

Mansi, S., W. Maxwell, and D. Miller. 2004. Does Auditor Quality and Tenure Matter to Investors? Evidence from the Bond Market. Journal of Accounting Research 42(4): $755-793$.

Noreen, E. 1989. Computerintensive Methods for Testing Hypothesis: An Introduction. New York, NY: Wiley.

O'Sullivan, K. 2009. The Tax Men Cometh. CFO, May 2009, 40-44.

Ou, C., and V. Williams. 2009. Lending to Small Businesses by Financial Institutions in the United States: Small Business Administration.

Petersen, M. A. 2004. Information: Hard and Soft. Working paper.

Petersen, M. A., and R. G. Rajan. 1994. The Benefits of Lending Relationships: Evidence from Small Business Data. The Journal of Finance 49 (1):3-37.

Pittman, J. A., and S. Fortin. 2004. Auditor choice and the cost of debt capital for newly public firms. Journal of Accounting $\mathcal{E}$ Economics 37(1): 113-136.

Puhani, P. 2000. The Heckman Correction for Sample Selection and Its Critique. Journal of Economic Surveys 14(1): 53-68.

Ribstein, L. 2007. The Rise of the Uncorporation. In University of Illinois Legal Working Paper Series. : University of Illinois. 
Rice, T., and P. E. Strahan. 2008. Does Credit Supply Affect Small-Firm Finance? Working paper.

Richardson, S., R. Sloan, M. Soliman, and I. Tuna. 2005. Accrual reliability, earnings persistence and stock prices. Journal of Accounting and Economics 39(3): 437-485.

Shehata, M. 1991. Self-Selection Bias and the Economic Consequences of Accounting Regulation: An Application of Two-Stage Switching Regression to SFAS No. 2. The Accounting Review 66 (4):768-787.

Sinkey, J. 2002. Commercial Bank Financial Management. 6th ed. Upper Saddle River, NJ: Prentice Hall.

Sinnett, W., and C. Graziano. 2006. What Do Users of Private Company Financial Statements Want? Financial Executives Research Foundation.

Sloan, R. G. 1996. Do Stock Prices Fully Reflect Information in Accruals and Cash Flows about Future Earnings? The Accounting Review 71 (3):289-315.

Stein, J. 2003. Agency, Information and Corporate Investment. In Handbook of the Economics of Finance, edited by G. Constantinides, M. Harris and R. Stulz: Elsevier Science B.V., 109-163.

Stiglitz, J. and A. Weiss. 1981. Credit Rationing in Markets with Imperfect Information. The American Economic Review 71(3): 393-410.

Teoh, S. H., and T. J. Wong. 1993. Perceived Auditor Quality and the Earnings Response Coefficient. The Accounting Review 68(2): 346-366. 
Titman, S., and B. Trueman. 1986. Information quality and the valuation of new issues. Journal of Accounting and Economics 8(2): 159-172.

Townsend, R. M. 1979. Optimal contracts and competitive markets with costly state verification. Journal of Economic Theory 21(2): 265-293.

Verrecchia, R. E. 1982. Information Acquisition in a Noisy Rational Expectations Economy. Econometrica 50(6): 1415-1430.

Wallace, W. A. 2004. The Economic Role of the Audit in Free and Regulated Markets: A Look Back and a Look Forward. Research in Accounting Regulation 17: 267-298.

Watts, R. L. 1977. Corporate Financial Statements, A Product of the market and political processes. Australian Journal of Management 4.

Watts, R. L., and J. L. Zimmerman. 1983. Agency Problems, Auditing, and the Theory of the Firm: Some Evidence. Journal of Law and Economics 26(3): 613-633.

—. 1986. Positive Accounting Theory. Englewood Cliffs, N.J.: Prentice Hall.

Waymire, G. B. 2009. Exchange Guidance is the Fundamental Demand for Accounting. The Accounting Review 84(1): 53-62.

Weber, J., and M. Willenborg. 2003. Do Expert Informational Intermediaries Add Value? Evidence from Auditors in Microcap IPOs. Journal of Accounting Research 41(4): 681-720.

Willenborg, M. 1999. Empirical Analysis of the Economic Demand for Auditing in the Initial Public Offerings Market. Journal of Accounting Research 37(1): 225-238. 